\title{
A FIELD STUDY OF BRINE DRAINAGE AND OIL ENTRAINMENT IN FIRST-YEAR SEA ICE*
}

\author{
By Seelye Martin \\ (Department of Oceanography WB-ro, University of Washington, Seattle, Washington 98 195, \\ U.S.A.)
}

\begin{abstract}
From field observations this paper describes the growth and development of first-year sea ice and its interaction with petroleum. In particular, when sea ice initially forms, there is an upward salt transport so that the ice surface has a highly saline layer, regardless of whether the initial ice is frazil, cone surface salt liquifies and drains through the ice, leading to the formation of top-to-bottom brine channels and void spaces in the upper part of the ice. If oil is released beneath winter ice, then the oil becomes entrained in thin lenses within the ice. In the spring, this oil flows up to the surface through the newly-opened brine channels and distributes itself within the brine-channel feeder systems, on the ice surface, and in horizontal layers in the upper part of the ice. The paper shows that these layers probably form from the interaction of the brine drainage with the percolation of melt water from surface snow down into the ice and the rise of the oil from below. Finally in the summer, the oil on the surface leads to melt-pond formation. The solar energy absorbed by the oil on the surface of these melt ponds eventually causes the melt pond to melt through the ice, and the oil is again released into the ocean.
\end{abstract}

RÉsumé. Une étude sur place du drainage de la saumure et de l'entrainement du pétrole répandu dans de la glace de mer de première année. A partir d'observations de terrain, cet article décrit la croissance et le développement de la glace de mer de première année et de ses interactions avec le pétrole. En particulier, lorsque la glace de mer commence à se former, il y a un transport de sel vers le haut de sorte que la surface de la glace possède un niveau de haute salinité, que la glace initiale soit du frésil de la glace columnaire ou du "slush". Lorsque la glace se réchauffe au printemps, en raison du phénomène d'eutexie, le sel de surface se liquéfie et s'écoule à travers la glace, conduisant à la formation de chenaux de saumure de haut en bas et d'espaces vides dans la partie supérieure de la glace. Si le pétrole est répandu sous la glace de l'hiver, il est entrainé en minces lentilles dans la glace. Au printemps, le pétrole reflue jusqu'à la surface par les chenaux de saumure qui viennent de s'ouvrir et se répartit lui-même dans le réseau des conduits de saumure, à la surface de la glace et dans les niveaux horizontaux de la partie supérieure de la glace. L'article montre que ces niveaux se forment probablement par l'interaction de l'écoulement de la saumure, de la percolation de l'eau de fusion de la neige de surface à travers la glace et la remontée du pétrole depuis le dessous. Finalement en été, le pétrole en surface conduit à la formation de bassins de fusion. L'énergie solaire absorbée par le pétrole à la surface de ces bassins de fusion peut éventuellement les conduire à se vidanger par fusion à travers la glace, et le pétrole est à nouveau répandu dans l'océan.

Zusammenfassung. Eine Felduntersuchung des Soleabflusses und des Ölgehalts in einjährigem Meereis. Auf Grund von Feldbeobachtungen beschreibt dieser Beitrag das Wachstum und die Entwicklung einjährigen Meereises und dessen Wechselwirkung mit Erdöl. Wenn Meereis sich zu bilden beginnt, findet im einzelnen ein Aufwärtstransport von Salz statt, dem zufolge auf der Eisoberfläche eine stark salzhaltige Schicht entsteht, unabhängig davon, ob das Eis zuerst Locker-, Säulen- oder Matscheis ist. Bei der Erwärmung im Frühjahr verflüssigt sich das Oberflächensalz infolge seiner eutektischen Konsistenz und fliesst durch das Eis ab, was zur Bildung von Solekanälen durch die ganze Eistafel und von Hohlräumen im oberen Bereich des Eises führt. Wird Öl unter Wintereis abgelassen, dann wird das Öl in Form dünner Linsen vom Eis aufgenommen. Im Frühjahr fliesst dieses Öl durch die neu eröffneten Solekanäle zur Oberfläche empor und verteilt sich im Zubringersystem der Solekanäle an der Oberfläche und in horizontalen Schichten im Oberteil des Eises. Es wird gezeigt, dass sich diese Schichten vermutlich aus der Wechselwirkung des Soleabflusses mit dem Absickern von Schmelzwasser aus dem Oberflächenschnee in das Eis und dem Aufsteigen des Öls von unten bilden. Im Sommer führt schliesslich das Öl zur Bildung von Schmelzpfannen an der Oberfläche. Die von diesen Pfannen absorbierte Sonnenenergie verursacht gelegentlich ein Durchschmelzen der Pfannen durch die Eistafel, wodurch das Öl wieder dem Meer zugeführt wird.

\section{INTRODUGTION}

Since 1974 the author has participated in a number of field and laboratory experiments on oil absorption by sea ice, which were motivated by the prospect of offshore oil-lease sales in the United States and Canadian Arctic. In the present paper we describe from observations in the Beaufort Sea how the change in properties of first-year sea ice throughout the year determines the interaction of oil with ice.

* Department of Oceanography, University of Washington. Contribution No. 1 I I4; Department of Atmospheric Sciences, University of Washington. Contribution No. 522. 
The observations come from three sources: (I) the NORCOR oil-in-ice field experiment during the 1974-75 ice-growth season which was conducted for the Canadian Beaufort Sea Project (described in Anonymous (1975), hereafter called the NORCOR report); (2) field observations of unoiled first-year ice growth by this author and his colleagues in the Beaufort Sea north of Alaska for the United States Outer Continental Shelf Environmental Assessment Program (OCSEAP) during $1975^{-78}$; (3) laboratory studies on the growth of oiled and unoiled sea ice.

In the following, much of our data consists of photographs of $76 \mathrm{~mm}$ diameter ice cores taken with a SIPRE corer. Depending on whether the resultant core was oiled or unoiled, we used several different photographic techniques. In the NORCOR field observations, we generally placed the oiled core on a sheet of oil absorbent, a white felt-like material, then photographed the core either with a front flash or by natural light. Figure I6a shows a typical oiled ice core. For unoiled sea ice, we treated the cores to enhance their photographic contrast in the following way: First, we cut the core longitudinally in half. Then we rubbed the flat surface of the half core with an alcohol-water solution which dissolved the saw cuts and melted away some of the surface so that the crystal structure stood out. Finally, we rubbed the ice surface with an oil-soluble dye which settled in the cracks between the individual crystals, thus greatly increasing the contrast.

To photograph the unoiled cores, we used either a front or back flash. In the fall 1975 OCSEAP traverse we used a front flash; Figure 3 a shows an example. After that time we used a back flash, which consisted of a box containing a half-cylinder "Plexiglas" (polymethylmethacrylate) insert with flash tubes beneath it. To photograph the core, we placed the dyed half-core in the box, then took a flash photograph. Figure 9a, a typical photograph, shows that this technique not only shows the crystal structure, but also brings out the presence of air bubbles within the ice.

The temperature profile within the ice was also determined in two different ways. In the NORCOR experiments several thermistor chains were frozen into the ice and the temperatures sampled throughout the ice season. In our OCSEAP observations, we determined the temperature profile from the ice core. Immediately after pulling the core, we placed it inside an insulated box with a cylindrical cut-out so that the box fitted snugly around the ice. Because ice has a thermal diffusivity of about $10^{-6} \mathrm{~m}^{2} \mathrm{~s}^{-1}$ and the ice core has a radius of about $38 \mathrm{~mm}$, the time in which the ice will equilibrate to a uniform outside temperature even without insulation is about $\mathrm{I} 500 \mathrm{~s}$ or 25 minutes. We sampled the ice-core temperature by drilling holes into the core at $50 \mathrm{~mm}$ intervals through holes pre-placed in the insulation. We placed thermistors into the drilled-out holes and measured their resistance with an ohmmeter. The resistances were then converted to temperatures using a programmable hand calculator; the accuracy of these measurements was about o. I deg.

Finally, we determined the salinity profile of the core by cutting it into transverse sections with thicknesses of 50-100 mm, melting these sections down, and measuring their salinities with an optical salinometer which was accurate to $0.2 \%$. For each core, we also sampled the salinity of the surface snow, the salinity of salt flowers if they occurred, and the surface salinity. To determine surface salinity we would clean the snow off the ice, scrape up a sample I $-3 \mathrm{~mm}$ thick from the ice surface with a chisel, then melt the sample and measure its
salinity.

The initial purpose of these detailed surface measurements was to verify certain qualitative observations made by Ramseier and others (1975, p. 26o-64) during March 1974 in the
U.S.S.R./U.S.A. Bering Sea Experiment. They observed at several sites that sea ice less than $0.26 \mathrm{~m}$ thick was covered with salt flowers and had a moist, high-salinity surface layer. They found that the salinities of these surface layers were greater than the $0-40 \%$ range of their conductivity bridge. From airborne passive microwave-radiometer measurements, they also established the importance of these surface layers by showing that the high surface salinity of 
thin ice lowers the ice emissivity to the extent that at certain frequencies, thin ice has the same brightness temperature as thick, multi-year ice.

In the following sections we describe how the first-year sea ice properties change and interact with oil over a growing season. To summarize, Sections 2-4 describe the growth and behavior of unoiled ice, and Sections $5-7$ describe the interaction of oil with this ice over a year.

In the sections on unoiled ice, Section 2 describes the initial growth of columnar, frazil, and slush ice, and in particular shows that in each case ice growth is accompanied by the formation of a high-salinity surface layer. Section 3 describes a kind of porous ice called snow ice which forms in the winter on the sea-ice surface under snow from the interaction of solar radiation with the snow and ice. Section 4 shows how the combination of the spring warming and the surface salt layer leads to the formation of top-to-bottom brine drainage channels.

In the oiled-ice sections, Section 5 describes how an oil spill is entrained under first-year winter sea ice, and discusses the subsequent oil behavior as the ice warms up and the oil flows to the surface through the brine channels. Section 6 describes two special cases; an investigation of the oil spill adjacent to a small pressure-ridge keel, and a spill under sea ice made up of parallel crystals. Finally, Section 7 describes how oil on the ice surface leads to oiled meltpond formation and the subsequent release of this oil back into the ocean.

\section{The initial growth and Development of FiRst-year SEA IGE}

Sea ice begins its growth in several ways; in the following we consider the initial growth of three different kinds of ice, namely columnar, frazil, and slush ice, which grow from sea-water mixed with snow. In each of these three cases, our observations show that the ice forms with a high surface salinity.

\section{I. Columnar ice}

Columnar ice begins its growth from quiescent sea-water. For example, Figure I shows a photograph of a newly opened lead taken on 7 November 1975 north of Barter Island, Alaska. For this lead the air was calm with a temperature of $-30.5^{\circ} \mathrm{C}$, while the sea-water salinity was $32 \%$. In the right foreground the tape measure rests on ice which is $0.3^{8} \mathrm{~m}$ thick. Immediately adjacent to this ice, new ice is growing where the rough surface material on the new ice is salt flowers. This ice, which extends out about $\mathrm{I} \mathrm{m}$, has a thickness of $35 \mathrm{~mm}$ and a salinity of $16 \%$, while the salt-flower salinity is $54 \%$. Beyond this salt-flower-covered ice, on what appears to be open water, we found that $10 \mathrm{~mm}$ of ice with a $19 \%$ salinity covered the lead. (We sampled this thin ice with an ice chisel, and determined that the rest of the lead was ice-covered by throwing bits of snow out onto the surface.) As illustrated by the diffusion of sunlight in the upper left-hand corner of the photograph, water vapor rose from the entire lead surface. The presence of both the vapor and the salt flowers shows that a movement of salt water up through the ice characterizes the initial ice formation. The importance of this initial upward movement of salt and water through the ice is that it establishes a high surface salinity. This high surface salinity both in part determines the subsequent surface properties of the ice and contributes to growth of brine channels in the spring.

As Nelson (1969, p. 20-23) describes, Eskimo hunters and other Arctic travelers have known, probably for centuries, of this salty layer on the surface of young sea ice. In previous determinations of ice salinity, however, this layer has been overlooked because the ice salinity profile was generally measured from cores cut into sections 50-100 $\mathrm{mm}$ long, which were then melted down for salinity (for example, see Weeks and Lee (1962)). With this technique, which gives useful data for the calculation of sea-ice strength, the high salinity of the thin surface layer is averaged out in the top core sample. 


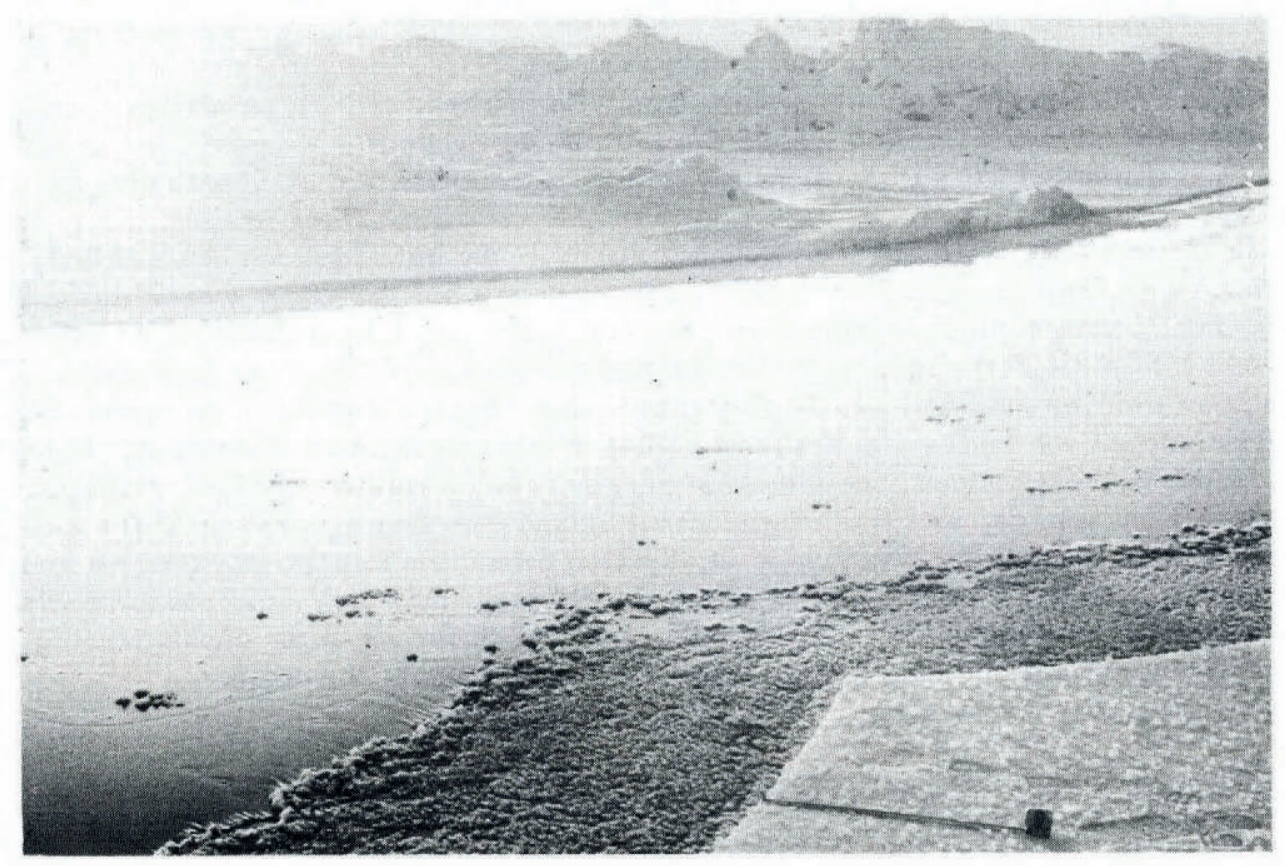

Fig. I. A newly-opened lead, 7 November 1975.



Fig. 2. A photograph of salt flowers taken on 21 February 1976 in the Beaufort Sea. The chisel blade measures 60 mm across. 
To illustrate the salt flowers, Figure 2 shows a close-up photograph made on a separate occasion at an air temperature of $-36.4^{\circ} \mathrm{C}$. The salt flowers consist of delicate crystals of frozen brine which grow to heights of $20-50 \mathrm{~mm}$. For this case the salt-flower salinity was $6 \mathrm{r} \%$. Salt flowers which occurred on most of our young ice samples taken in October and November, had salinities ranging from $45-95 \%$.

The ice growth from undisturbed water beneath the salt flowers, as Weeks ( 1976 ) describes, begins with very small, randomly oriented crystals in the top 10-20 $\mathrm{mm}$ of the core; below this depth the ice consists of long columnar crystals with a horizontal $c$-axis. Figure $3 a$, an example of a typical columnar core, shows this characteristic structure; and Figure $3 \mathrm{~b}$ shows the salinity and temperature profiles of the core. Most of this core has a salinity of 8-10\% except at the ice surface, where the salinity is $50 \%$. The $10 \mathrm{~mm}$ thick snow layer also has a high salinity which is presumably caused by salt flowers within the snow.

Finally, the bottom ro-40 $\mathrm{mm}$ of columnar sea ice is called the skeletal layer; this ice is both porous and fragile. Figure $3 \mathrm{c}$ shows a bottom view of columnar laboratory ice; dye, rubbed on the ice, outlines the individual platelets, where groups of platelets with the same orientation are called crystals. As discussed below, the porous ice of the skeletal layer also absorbs oil spilled beneath the ice.

\subsection{Frazil ice}

Frazil ice grows when a cold wind blows over sea-water which is at its freezing point; the wind generates waves which stir the water. The stirring prevents the growing ice crystals from organizing themselves into the long columnar platelets; rather, as Martin and others (1979) show, the water column becomes slightly supercooled so that ice crystals form in the interior and float to the surface. These crystals are platelets with typical thicknesses of $\mathrm{I}-\mathrm{Io} \mu \mathrm{m}$ and diameters of $\mathrm{I}-2 \mathrm{~mm}$. Once these crystals reach the surface, they form a porous mass with a random crystal structure. Because in our fall and winter field traverses high winds were often accompanied by blowing snow which mixed with the sea-water to form a third kind of ice discussed in the next section, we took our best frazil ice cores in May.

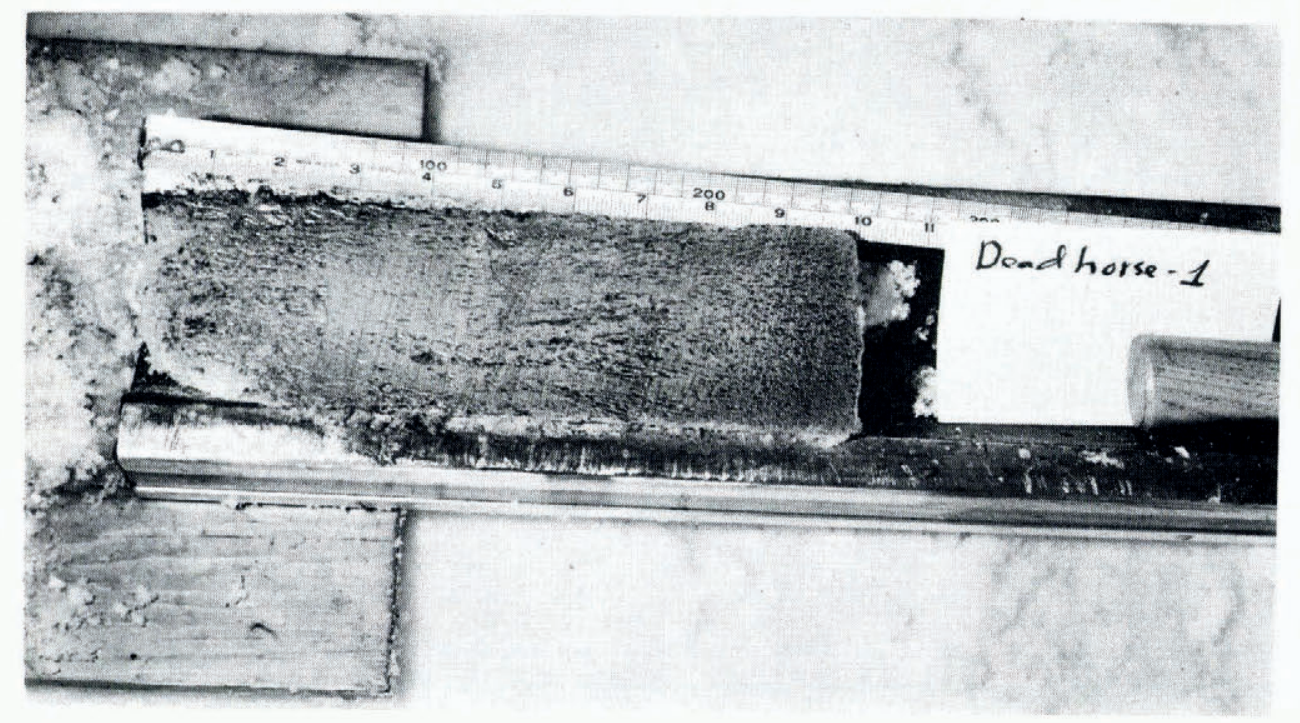

Fig. $3 a$ 


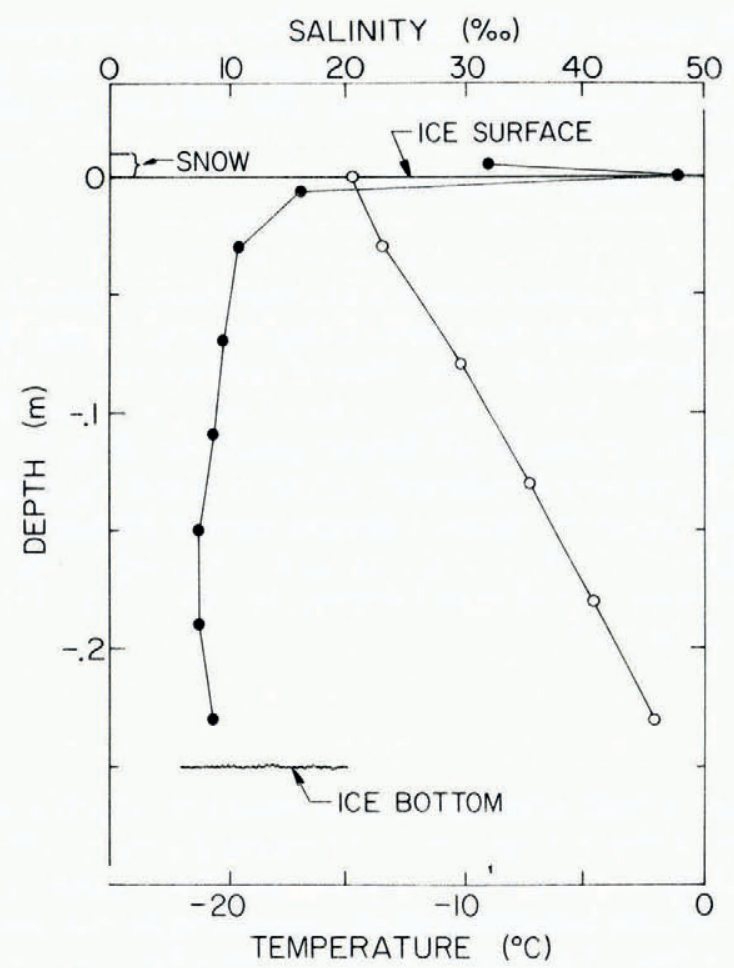

Fig. $3^{b}$

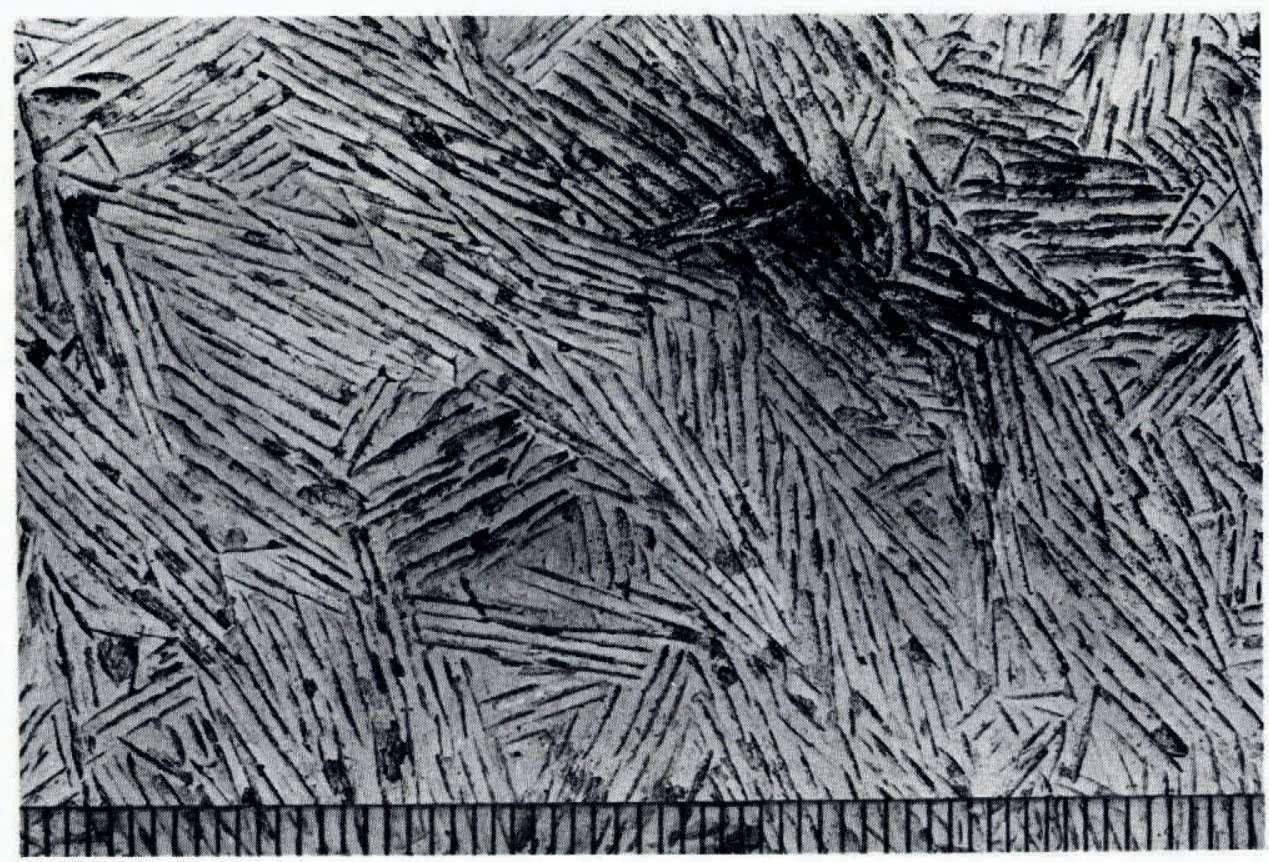

Fig. $3 c$ 


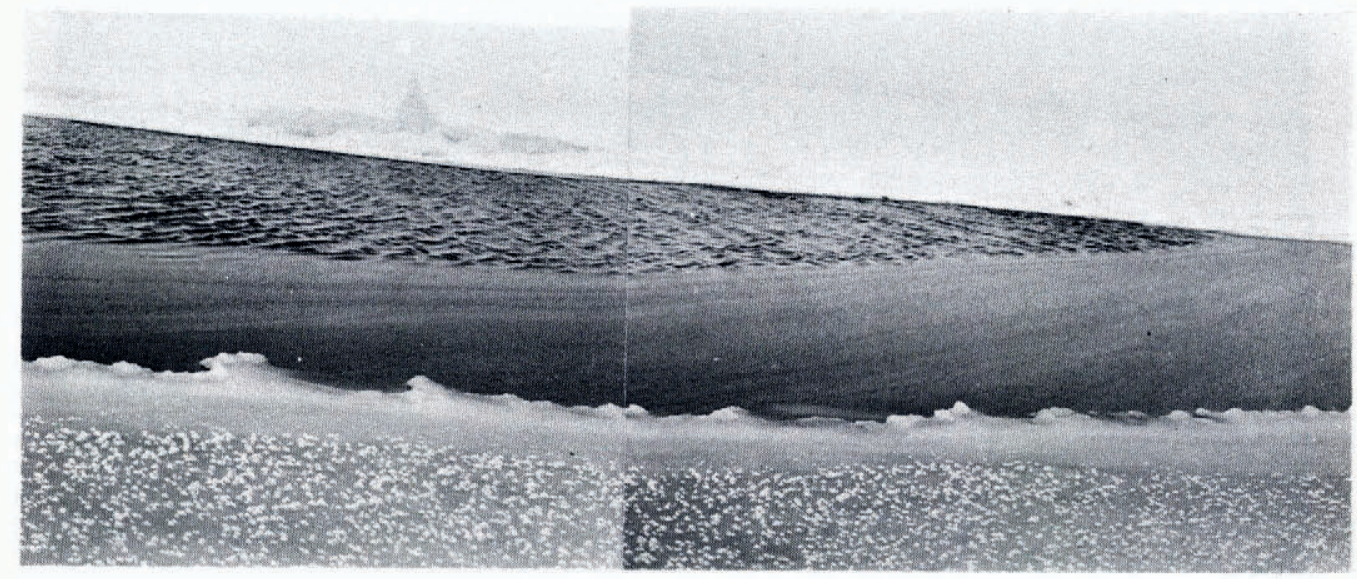

Fig. 4. Frazil ice growing in an open lead, 18 May 1976 . The white dots in the foreground are salt flowers.

Figure 4 is a composite photograph taken on 18 May 1976 of the formation of frazil ice in an open lead with a $50 \mathrm{~m}$ fetch. The wind velocity was about $10 \mathrm{~m} \mathrm{~s}^{-1}$ and the air temperature was $-13^{\circ} \mathrm{C}$. Because of the combination of wind and wave herding, the crystals were swept down-wind to pile up at the edge of the lead, where they formed a slushy ice mass which was about $0.1 \mathrm{~m}$ thick. Figure 5 a shows a core taken on 23 May 1976 through such a lead after it had frozen solid. The top $95 \mathrm{~mm}$ of the core in Figure $5 \mathrm{a}$ is made up of the small frazil crystals, below which there is an abrupt transition to columnar ice. Figure $5 \mathrm{~b}$ shows the salinity and temperature profile of this core; even though this ice grows under warm conditions, its surface salinity is still relatively large.

\subsection{Ice grown from snow mixed with sea-water}

A third kind of ice forms when blowing snow accompanies the wind. Figure 6 a shows a core taken on 7 November 1975 north of Barter Island, Alaska, at an air temperature of $-30^{\circ} \mathrm{C}$; because the days preceding the pulling of this core were characterized by high winds and blowing snow, we suspect that the small grainy structure of the upper $105 \mathrm{~mm}$ of this core formed from a mixture of snow crystals and sea-water. Figure $6 \mathrm{~b}$ shows the salinity and temperature profiles for the core in Figure $6 \mathrm{a}$; the salinity profile shows both a high surface salinity and that there is no sharp salinity change at the depth where the columnar ice growth begins.

In summary, the preceding three cores, which we feel are a characteristic selection among the many cores which we sampled, have a high surface salinity. Further, for both the frazil and slush-ice core, the transition between the region of randomly oriented crystals and the columnar growth takes place abruptly. As we show below, this abrupt transition may also be reflected in the way in which oil is absorbed.

Fig. 3. Columnar ice. (a) Ice core taken north of Deadhorse on 2 November 1975; core bottom is at left. (b) Salinity and temperature profile of the core shown in $(a)$; salinity , temperature $\bigcirc$. (c) The bottom of a columnar ice core; scale is in millimeters. 


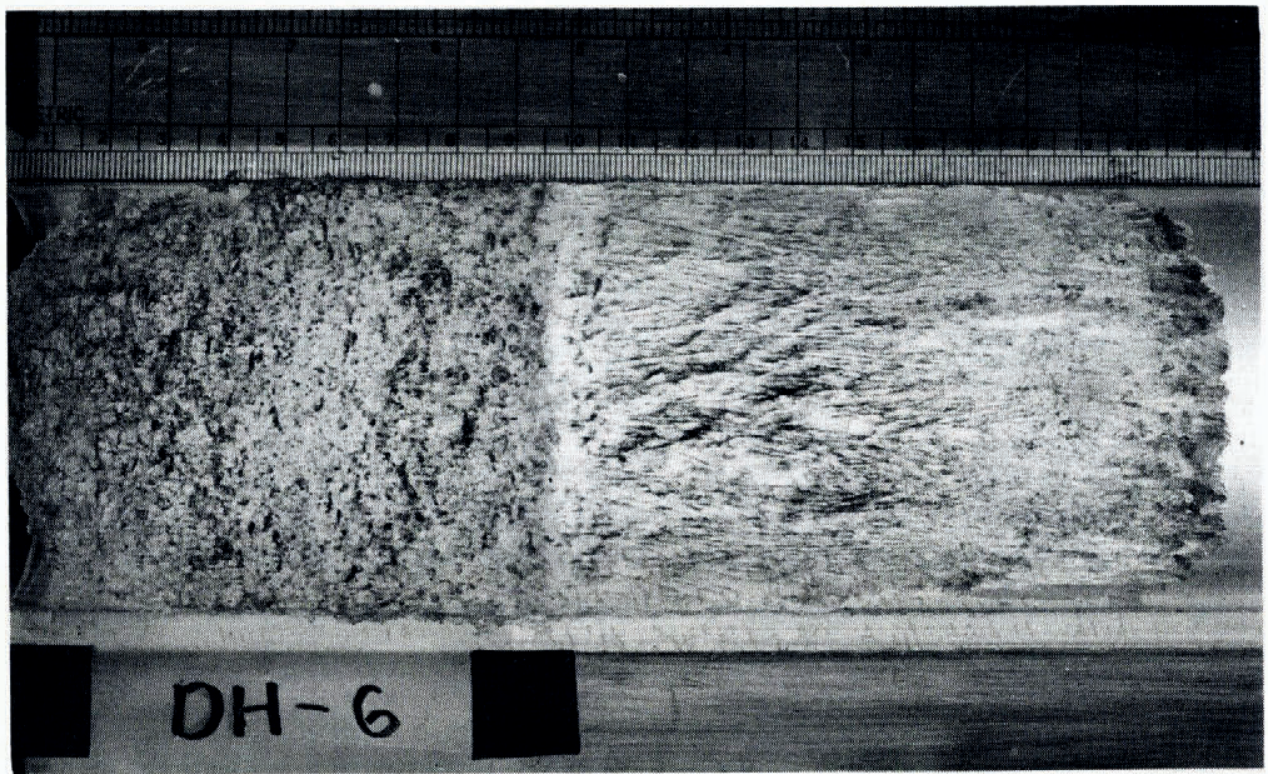

$a$

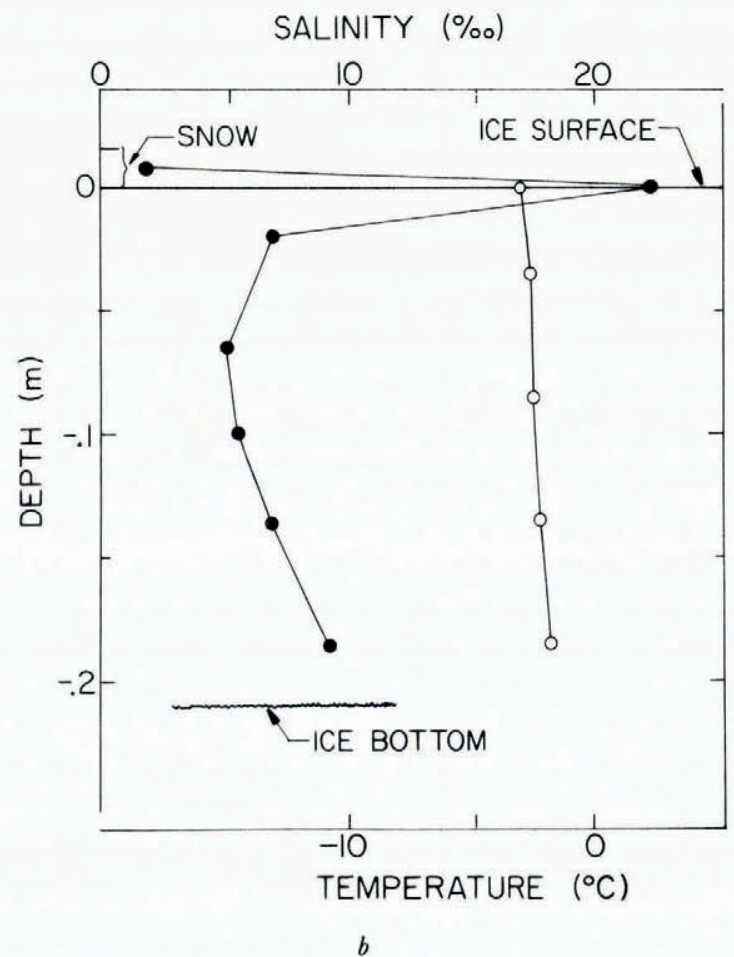

Fig. 5. Frazil ice. (a) Ice core showing both frazil and columnar ice taken 23 May 1976, core bottom is to right. (b) Salinity and temperature profile of the core shown in $(a)$; salinity 0 , temperature 0 . 


\section{SNOW IGE}

If snow covers the ice, then during the Arctic winter and spring a fourth kind of ice forms at the ice surface from the melting and refreezing of the overlying snow. The simplest way for the snow ice to form, as Weeks (1976) describes, is for the weight of the snow to depress the ice below the free surface so that sea-water floods the snow, which later refreezes. A more common way for snow ice to form is from the interaction of solar radiation with the snow layer. Because the snow immediately on the ice surface has a high salt content from the salt flowers, its freezing point is depressed, for example snow with a salinity of $100 \%$ has a solution freezing point of $-7^{\circ} \mathrm{C}$. The incident solar radiation melts and compacts this salty snow, whereupon the heat flux from the relatively warm snow to the cold ice below refreezes the snow into a hard porous saline layer with a thickness of ro-30 $\mathrm{mm}$. Figure 7 a shows such porous ice at the top of an ice core taken under $30 \mathrm{~mm}$ of snow in February 1976 at an air temperature of $-36^{\circ} \mathrm{C}$ north of Lonely, Alaska, and Figure $7 \mathrm{~b}$ shows the salinity and temperature profiles for the core. Comparison of Figure $7 \mathrm{~b}$ with Figure $3 \mathrm{~b}$ shows that the high surface salinity now appears to be spread out into the porous snow ice. As subsequent sections show, this porous ice will absorb oil on the ice surface.

\section{Brine drainage channels}

First-year ice generally grows to a thickness of $\mathrm{I}-2 \mathrm{~m}$ with a predominantly columnar crystal structure below the near-surface frazil ice. For oil entrainment, the most important ice features are the brine drainage channels or tubes extending up into the ice with diameters ranging up to $\mathrm{so} \mathrm{mm}$.

Brine channels occur in first-year ice for all of the growing season; however, their size and spatial frequency increases as the ice warms. The observations of Lake and Lewis (1970)

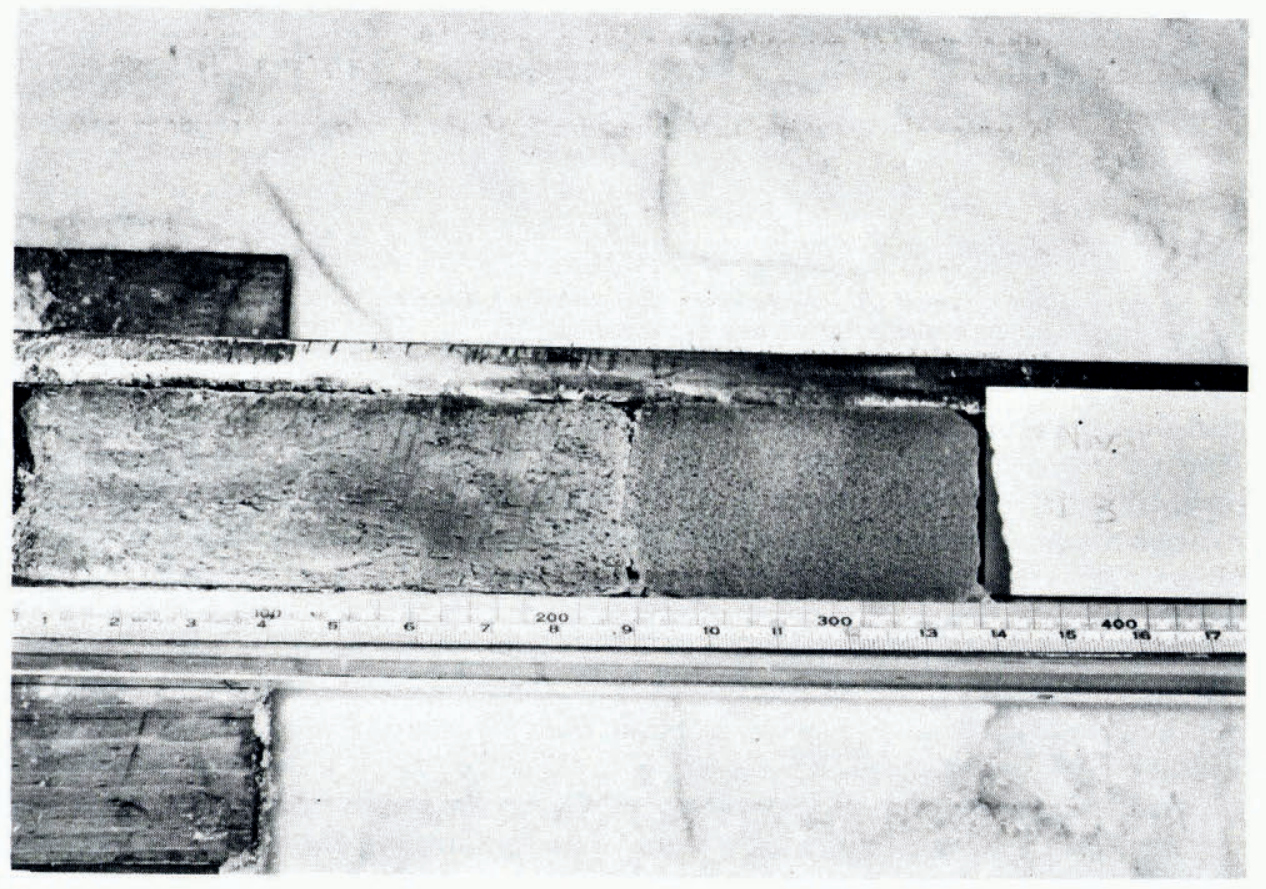

Fig. $6 a$ 


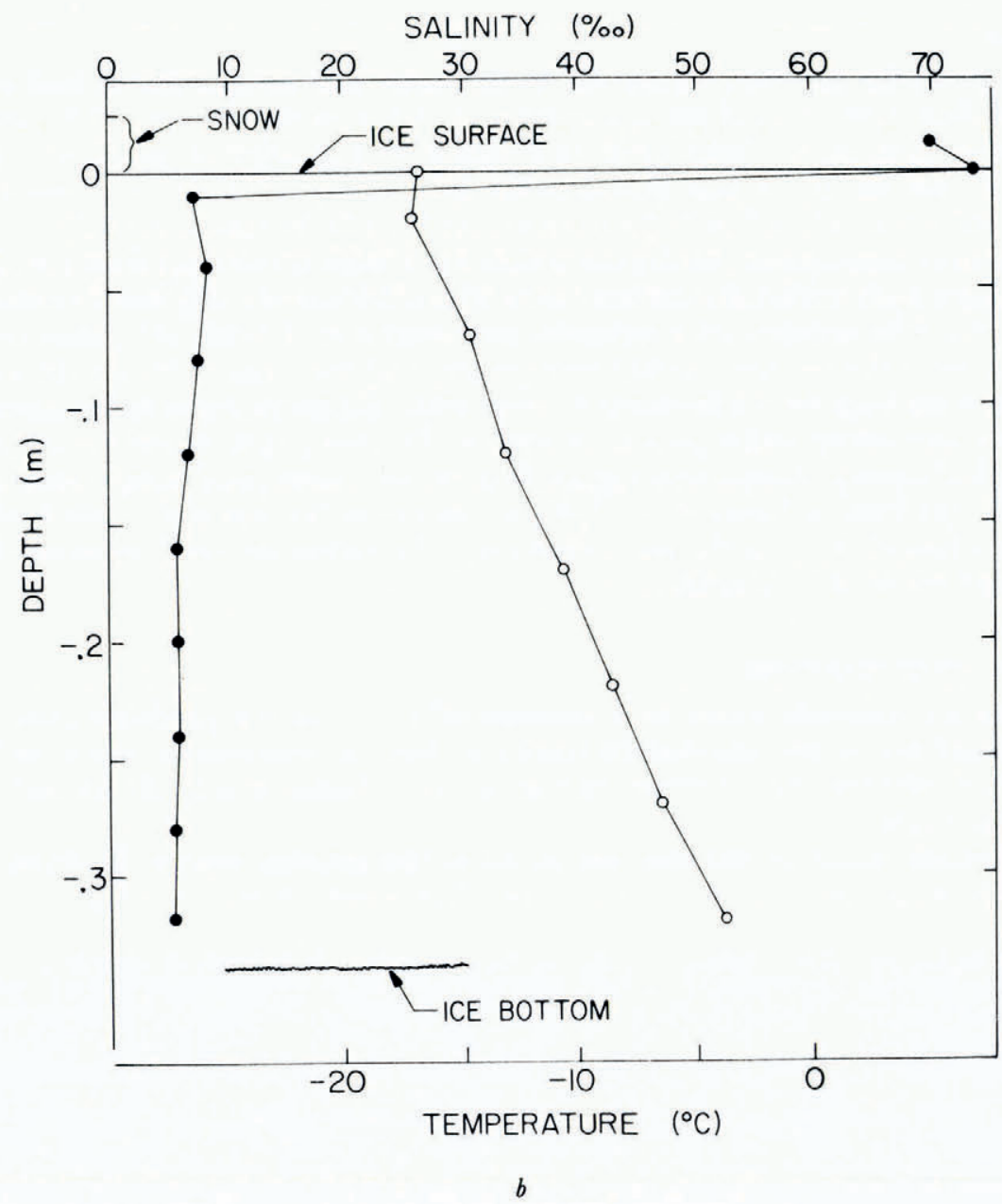

Fig. 6. Ice grown from snow mixed with sea-water. (a) Ice core taken 7 November 1975 , core bottom is at left. (b) Salinity and temperature profile for core in $(a)$; salinity

, temperature $\mathrm{O}$.

suggest that the brine drainage systems form between crystal boundaries with feeder channels coming in between the platelet boundaries. To illustrate the spatial frequency of brine channels, Figure 8 shows a previously unpublished observation made by Robert Lake of the brine-tube distribution at the bottom of a piece of first-year ice $1.6 \mathrm{~m}$ thick taken in February I 968 at Cambridge Bay, Northwest Territories, Canada; the brine channels have a characteristic spacing on a rectangular grid of about $0.1 \mathrm{~m}$. In this $1.6 \mathrm{~m}$ thick ice, these channels extended 0.1 to $0.5 \mathrm{~m}$ up into the ice.

In our observations we observed very few channels in the fall and winter. Indirect evidence of drainage channels, however, came from observations on rafted ice. In one case in November 1974, we observed a sheet of $0.3 \mathrm{~m}$ thick ice which was rafted up so that the ice was horizontal with its bottom exposed to air. When the ice was rafted, the brine within the ice drained out, leaving desalinated ice above and producing the growth of salty stalactites on the ice bottom. These stalactites, which probably marked the brine channel exits, also had about a $0.1 \mathrm{~m}$ grid spacing. 


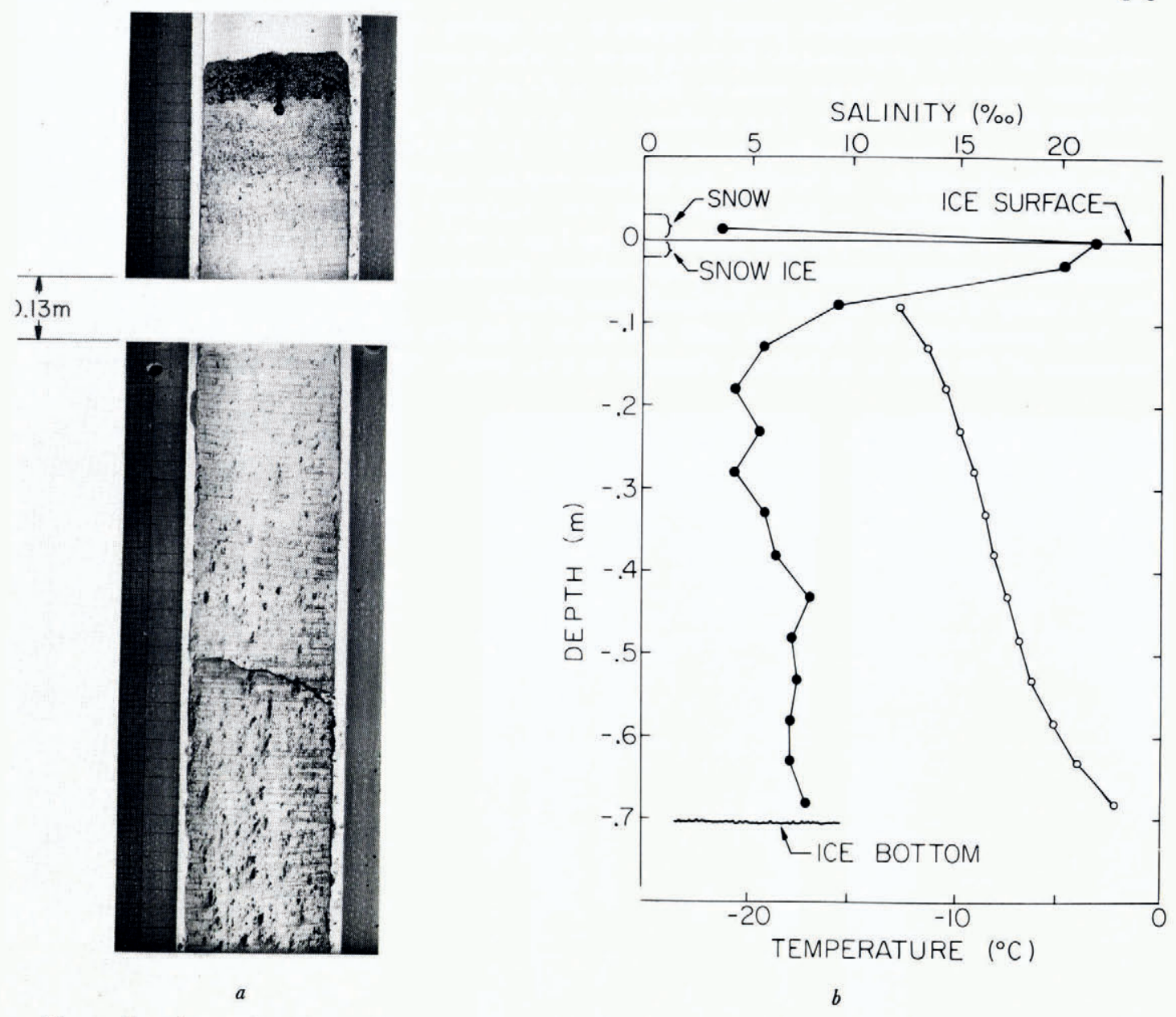

Fig. 7. Snow-ice growth on sea-ice surface. (a) Partial photograph of core taken on 20 February 1976; middle gap was caused by flash malfunction. (b) Salinity and temperature profile for core in $(a)$; salinity 0 , temperature $\bigcirc$; note scale change on salinity between $(7 b)$ and $(6 b)$.



Fig. 8. Sketch of the brine channel distribution on the bottom of first-year ice made in February 1968 by Robert Lake. Large circles have a diameter of about $10 \mathrm{~mm}$, large dots about $5 \mathrm{~mm}$, small dots about $1 \mathrm{~mm}$. 
The major brine-channel growth occurs in the spring, when both the air and the ice temperature warm up toward the freezing point. Under these conditions we observed channels in almost every core. As an example, Figure ga shows the upper $0.78 \mathrm{~m}$ of a core taken in Prudhoe Bay under $120 \mathrm{~mm}$ of snow about 2.5 nautical miles $(4.6 \mathrm{~km})$ south of Cross Island on $2 \mathrm{I}$ May 1976 at an air temperature of $-8.6^{\circ} \mathrm{C}$. In the lower portion of the core, a long brine channel is visible; the break in the channel may be caused by a slight rotation of the core during the longitudinal cutting. For the same core, Figure $9 \mathrm{~b}$ shows the salinity and temperature structure; the salinity profile shows that the high surface salinities present in the fall and winter cores are now replaced by near-zero values. The downward salt movement caused by the warming of the ice has led to brine-channel growth.

The photograph in Figure ga and our direct field observations show that the crystal structure of the core is as follows: From $0-20 \mathrm{~mm}$, frazil; from $20-150 \mathrm{~mm}$, a mixture of

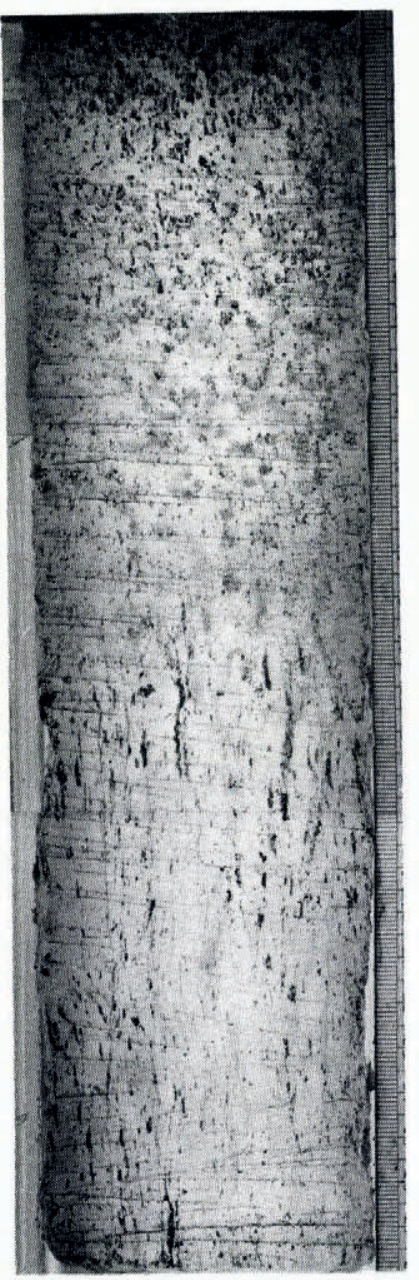

$a$

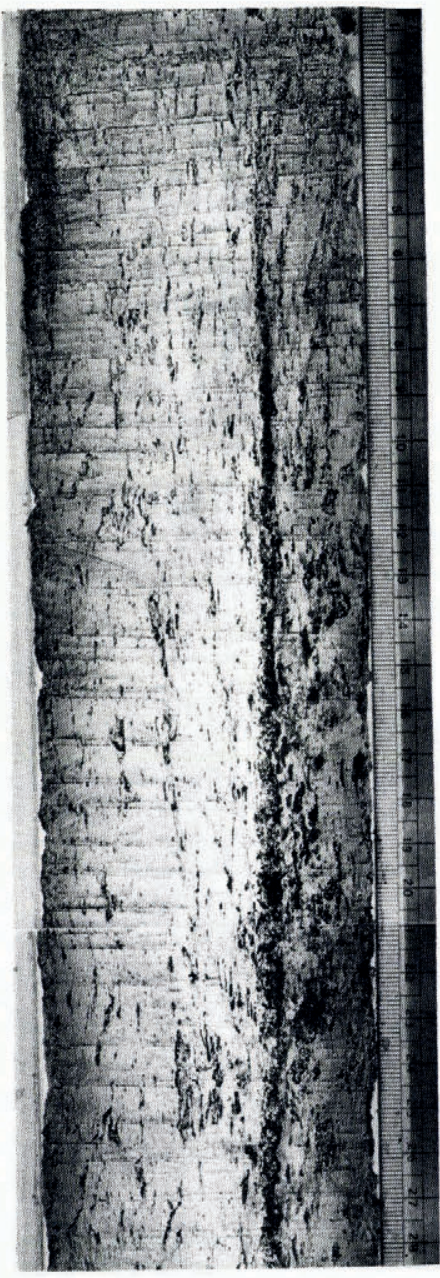

$b$

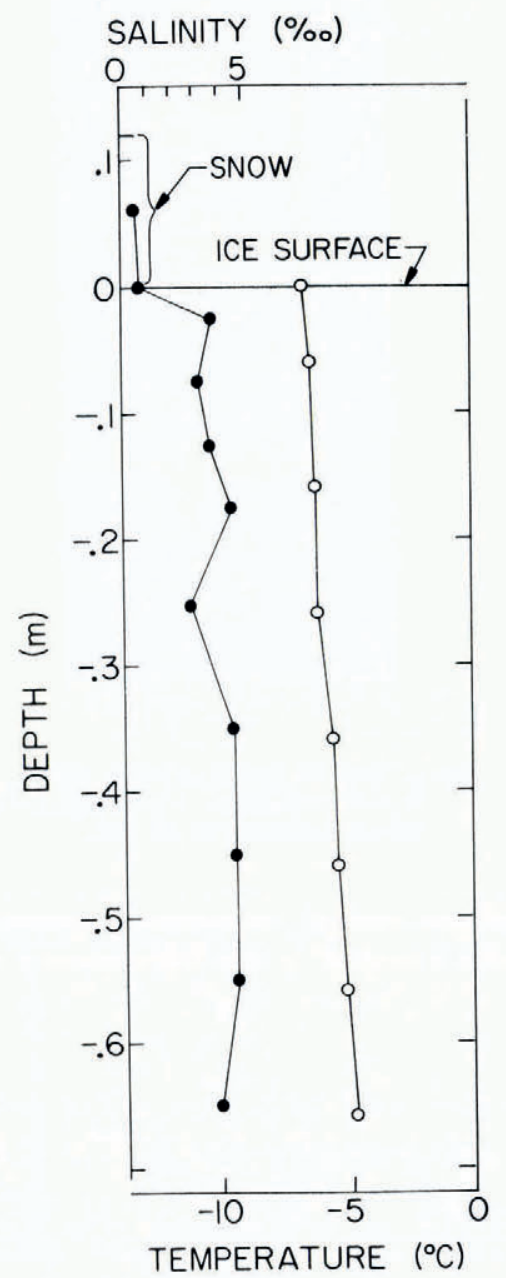

$c$

Fig. 9. Brine drainage channels in the spring. (a) The top $0.57 \mathrm{~m}$ of a core taken on 21 May 1976, top of core is at upper left, segment on right is the lower continuation of segment at left. (b) Salinity and temperature profile for $(a)$; salinity temperature $\mathrm{O}$. 
columnar and frazil; below I50 mm, columnar. Also above I50 mm, the shadows of air bubbles with diameters of $2-3 \mathrm{~mm}$ are visible. Judging by extrapolation of the temperature profile, the ice thickness is about $2 \mathrm{~m}$, which implies an ice freeboard of about $0.2 \mathrm{~m}$, so that the depth to which the air bubbles form is probably correlated with the freeboard. Our laboratory studies suggest that the air bubbles form in the following way. As the sea ice warms up, brine drains from the ice above the waterline leaving air-filled void spaces in its wake. These void spaces are generally interconnected and terminate at the water-line, since below the water-line, sea-water can flow up from below to replace the brine. If the ice is snow-covered, then fresh or low-salinity melt water from the snow is free to percolate down into this porous layer and refreeze either by heat loss to the colder ice below or to the atmosphere on a cold day. When the water refreezes, air bubbles form, both from the release of dissolved air from the freezing water, and possibly by entrapment of air in semi-enclosed channels. As discussed below, the field experiments with oil suggest that oil is entrapped in a similar way.

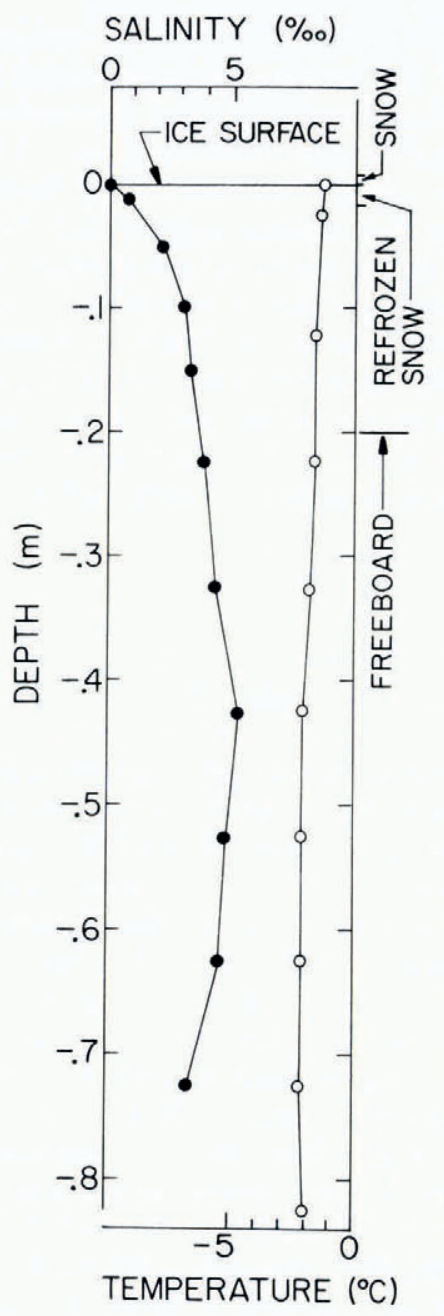

Fig. Io. The salinity and temperature profile of a very warm core taken on 26 May 1976 ; salinity $\bigcirc$, temperature $\bigcirc$. The freeboard of this core was determined from a nearby auger hole. 
When the ice becomes further desalinated, its surface salinity approaches $0 \%$. Figure ro shows the temperature and salinity profile of a core which is almost entirely columnar ice taken on 26 May 1976 at an air temperature of $-1.5^{\circ} \mathrm{C}$. The temperature is now nearly uniform within the ice at $-2^{\circ} \mathrm{C}$, and the ice surface salinity is $0 \%$. Further warming of this ice leads to the formation of melt ponds.

\section{OIl IN SEA IGE: Results From the NORCOR STUdy}

The NORCOR field experiment, which was carried out in Balaena Bay on the Cape Parry peninsula, Northwest Territories, Canada, studied the behavior of oil released at different times of the year under first-year ice. Two kinds of oil were used; a Norman Wells crude with a pour point of $-50^{\circ} \mathrm{C}$ and a specific gravity at $0^{\circ} \mathrm{C}$ of 0.845 and a Swan Hills crude with a pour point of $-5^{\circ} \mathrm{C}$ and a specific gravity at $0^{\circ} \mathrm{C}$ of 0.835 . A thorough description of the experiment and the oil properties are given in the NORCOR report; in this section we describe in detail the interaction of these oils with first-year ice.

Balaena Bay is a semi-enclosed bay connected to Amundsen Gulf, so that sea-water fills the bay. The NORCOR field log (private communication from David Dickens) shows that ice first formed in the bay during the night of 28 September 1974 at an air temperature of $-8^{\circ} \mathrm{C}$, a wind speed of $7 \mathrm{~m} \mathrm{~s}^{-1}$, and blowing snow. The snow continued through 29 September. The ice thickness was first sampled on 5 October, at which time the ice was o. $18 \mathrm{~m}$ thick. Our later coring observations suggest that the combination of wind and snow led to the growth of a slush-ice layer, the thickness of which varied from 70 to $180 \mathrm{~mm}$ within the test site. We discuss below how the presence of this slush-ice layer affects the oil absorption.

This author was at Balaena Bay for the periods 7-18 November 1974 and 10-31 May 1975, during which times he observed one winter and one spring spill. The oil interacted with the sea ice at three different times: first, immediately following the oil release; second, during the opening of the brine drainage channels and subsequent rise of the oil to the surface; and third, during the formation and drainage of oiled melt ponds. We first discuss the winter spills.

\subsection{The winter spills}

When oil is released under cold sea ice, it collects in both pools and droplets. Because sea ice has natural undulations in its underside, the oil tends to collect in inverted pools. Even if the ice bottom is perfectly flat, Lewis (1976) shows that because of surface tension the oil collects in droplets and lenses on the ice bottom with thicknesses of about 5-10 $\mathrm{mm}$. Because the oil layer is cooled from above and heated from below, convection may occur within the layer. As Wolfe and Hoult (1974) and the NORCOR report (Anonymous, 1975, p. 74-82) discuss, the heat transfer across the oil layer is a function of the Rayleigh number which is proportional to $h^{3} \Delta T$, where $h$ is the oil layer thickness, and $\Delta T$ is the temperature difference across the layer. If $h$ is sufficiently small, or on the order of $10 \mathrm{~mm}$, then the heat transfer within the layer takes place by conduction. For $h$ greater than $10 \mathrm{~mm}$, convection occurs within the layer, and the heat transfer may be much greater than the conductive value.

If the layer is sufficiently thin for the heat transfer to be by conduction alone, then because the thermal conductivity of sea ice is about $2.5 \mathrm{~W} \mathrm{~m}^{-1} \mathrm{deg}^{-1}$ (from Lewis, 1967 ), and that of crude oil is about $0.13 \mathrm{~W} \mathrm{~m}^{-1} \mathrm{deg}^{-1}$ (from Wolfe, unpublished), the oil is 20 times less conductive than the ice so that the oil layer under the ice acts as an insulating blanket. After a period of time the temperature profile within the ice and the ice-oil layer appears as in Figure II , so that the oil is colder than the surrounding sea-water.

This cooling of the oil leads to ice growth at both sides and bottom of the oil layer. At the sides, because the oil is colder than the surrounding water, as photographs in both Lewis (1976) and the NORCOR report show, a lip of ice grows laterally around the lens. This 


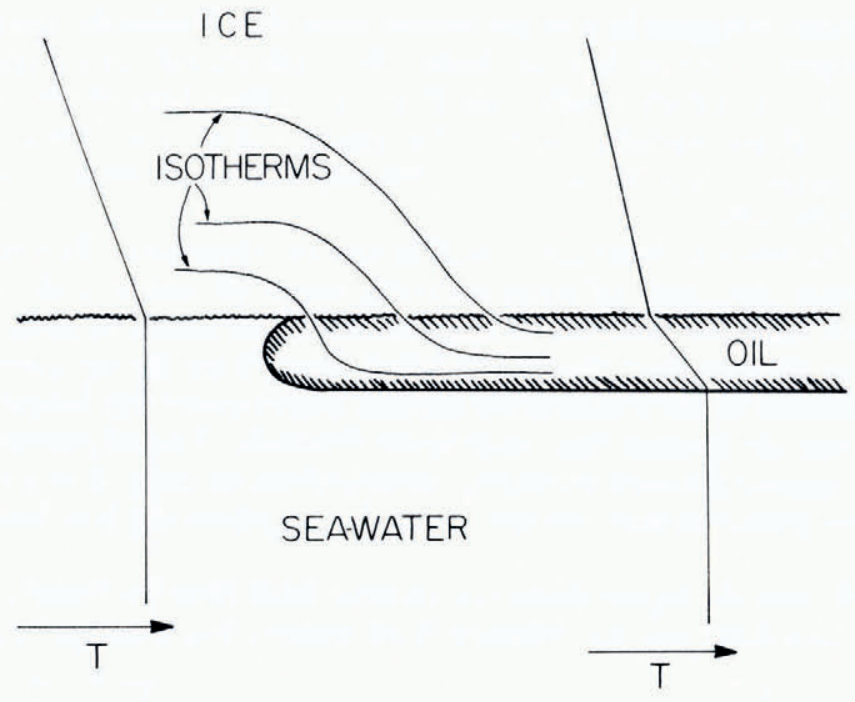

Fig. II. A sketch of the temperature profile and the location of isotherms both inside and outside of an oil lens.

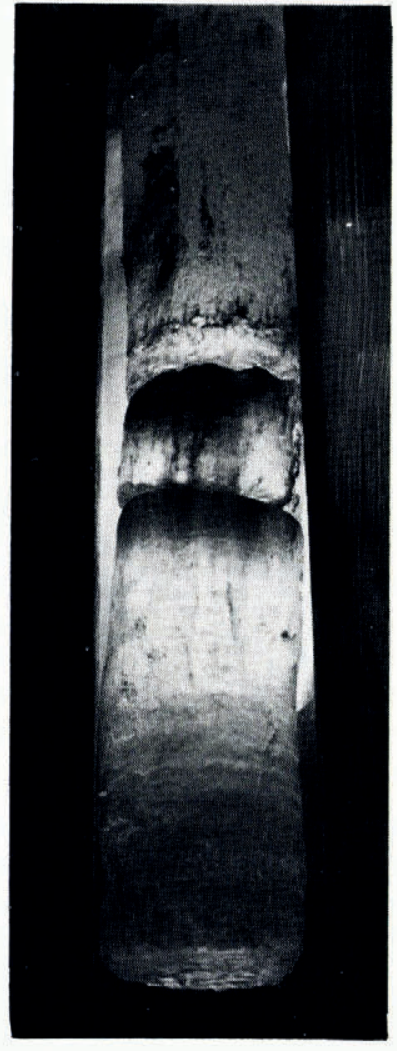

$a$

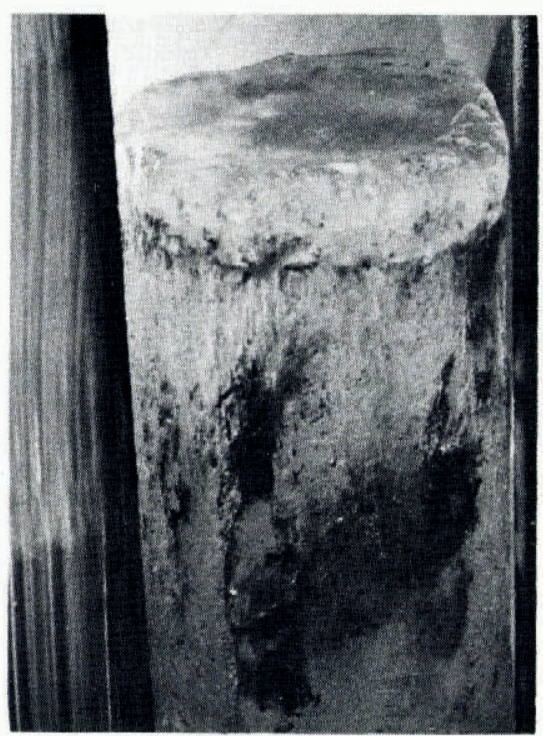

b

Fig. 12. Ice core taken through an oil spill on $1_{5}$ November 1974. (a) The whole core. (b) The ice directly beneath the oil lens. 
lateral oil containment happens in a much shorter time than it takes for the ice sheet to grow a vertical distance equal to the oil lens thickness. Beneath the oil, an ice layer with a vertical $c$-axis forms. In our laboratory studies, the first ice to form beneath oil resembles the thin horizontal platelets which initially form on the surface of an undisturbed fresh-water lake. In the field, this $c$-axis vertical ice grows to a thickness of about $10 \mathrm{~mm}$, after which the ice resumes columnar growth.

To illustrate this $c$-axis vertical ice as well as the oil absorption, Figure i 2a shows a core from the 24 October 1974 spill of Norman Wells crude oil under $0.3^{8} \mathrm{~m}$ thick ice. While taking the core, we observed that the oil lens thickness was about $10 \mathrm{~mm}$. In the figure, the oil lens location on the core is at the second break down from the top; above this break, the oil moved up uniformly 10-20 $\mathrm{mm}$ into the skeletal layer; above this height, the oil moved an additional 70-80 mm up through four small brine channels. The oil shown in the ice beneath the lens probably entered the core during its removal from the hole. From examination of this core at the site, we estimated that the first $50 \mathrm{~mm}$ of ice above the lens held about $5 \%$ oil by volume.

Beneath the oil lens, the figure shows the ro mm thick clear ice "cap". Figure 12b shows a close-up of the cap; there was no evidence of oil penetration through it, and beneath it the

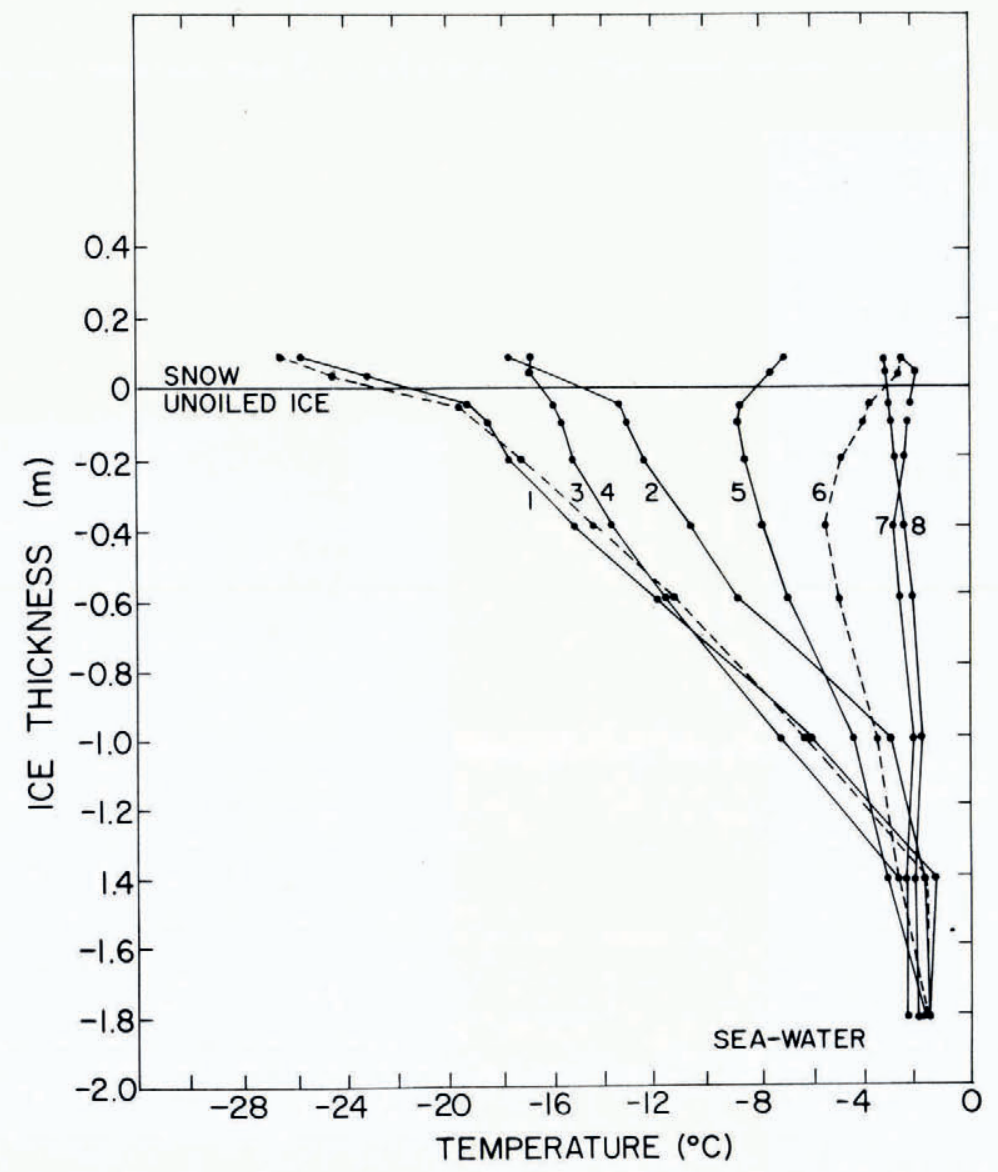

Fig. 13. Temperature profiles from the 1975 Balaena Bay test site. I. 15 February, 2. 28 February, 3. I6 March, 4. 31 March, 5. 15 April, 6. 3o April, 7. 14 May, 8. 22 May. 
ice abruptly resumed its columnar growth. We also observed this cap on several cores that we pulled in the spring. The cap, with the additional buoyancy of the new ice growth beneath it, tends to pressurize the oil lens so that, in the fall, coring into an oil lens resulted in a rapid upward flow of oil; in one instance oil spurted up around the SIPRE corer to a height of $0.3 \mathrm{~m}$ above the ice surface (private communication from David Dickens). The oil therefore is ready to flow upward and move out of the lens as soon as a path presents itself.

In summary, when oil is released under young columnar ice sheets, it collects in pools under the ice, where some of it is entrained in between the platelets in the skeletal layer, and some of it flows up into the brine channels. The observations made at the site through March I 975 shows that once in this configuration, the oil in the ice remained essentially static, with only a slight rise of oil up the brine channels as the ice began to warm.

\subsection{Spring behavior of oil and ice}

To illustrate the spring warming of the ice at the Balaena Bay site, Figure I 3 shows a selection of temperature profiles from a control thermistor chain in unoiled sea ice for the period I 5 February-22 May 1975. The figure shows that there was a warm period in April, where the air temperature increased from $-15^{\circ} \mathrm{C}$ to a maximum of $+10^{\circ} \mathrm{C}$, after which it again cooled down in May. Because of this strong warming, sometime in late April, top-tobottom brine channels in the ice opened up and observers at the site in early May saw oil on the ice surface under the snow.

The most important oil absorption mechanism is this opening of the top-to-bottom brine channels. This allows the oil both to rise through the ice to the ice surface, and to permeate the channel systems within the ice. There is also a complicated region near the ice surface where the oil is absorbed laterally in horizontal layers, apparently because of the interaction of melt water from the snow percolating down and oil rising up. In what follows, we first discuss an example of a top-to-bottom brine channels, then discuss the interaction of oil with the near-surface ice.

At $17.00 \mathrm{~h}$ on I 5 May 1975, we carried out a small oil discharge under $1.95 \mathrm{~m}$ of ice. Immediately preceding the experiment, we shoveled off the surface snow from the hard sea ice. Figure I 4 a shows the appearance of the ice surface before the discharge. The air temperature was about $-8^{\circ} \mathrm{C}$, the ice surface temperature taken from a nearby thermistor chain was $-3^{\circ} \mathrm{C}$. The discharge consisted of $0.4^{2} \mathrm{~m}^{3}$ of Norman Wells crude oil injected through a slanted discharge pipe in a 3 min period under the cleared area.

Forty-five minutes after the discharge, a single oil droplet with a $1 \mathrm{~mm}$ diameter appeared on the ice surface inside the cleared area. We marked the droplet location with a small nail. As time went on, the oil spread laterally from this point both over and within the ice surface; farther, at other points on the surface, droplets also appeared and spread laterally. Figure $14 \mathrm{~b}$ shows the surface appearance about two hours after the discharge, where the nail which marks the point of first appearance is slightly above the shadow of the post. The oil which is both within the ice and on the surface gives the ice a mottled appearance. The distance between the centers of the oiled areas varies from o. I to $0.5 \mathrm{~m}$, while the area diameters range from o. I to $0.2 \mathrm{~m}$. The spacing of these oiled blotches is consistent with Lake's observations in Figure 8.

Between $\mathrm{I} 5.00$ and $\mathrm{r} 6.00 \mathrm{~h}$ on the following day we pulled cores from the spill. For one of these, we centered the SIPRE barrel around the surface point of first appearance and cored down. Figure 15 a shows the resultant core, where the core bottom is to the left and the core length is $\mathrm{I} .95 \mathrm{~m}$. Except at the very bottom of the core, the ice was hard to the touch. The photograph clearly shows the oil-filled brine channel running throughout the core length, with smaller feeder channels running diagonally from the central channel. Figure i $5 \mathrm{~b}$ is a close-up of the large bottom core segment in Figure $15 \mathrm{a}$; the main channel in the ice bottom was large enough to hold a pencil. 


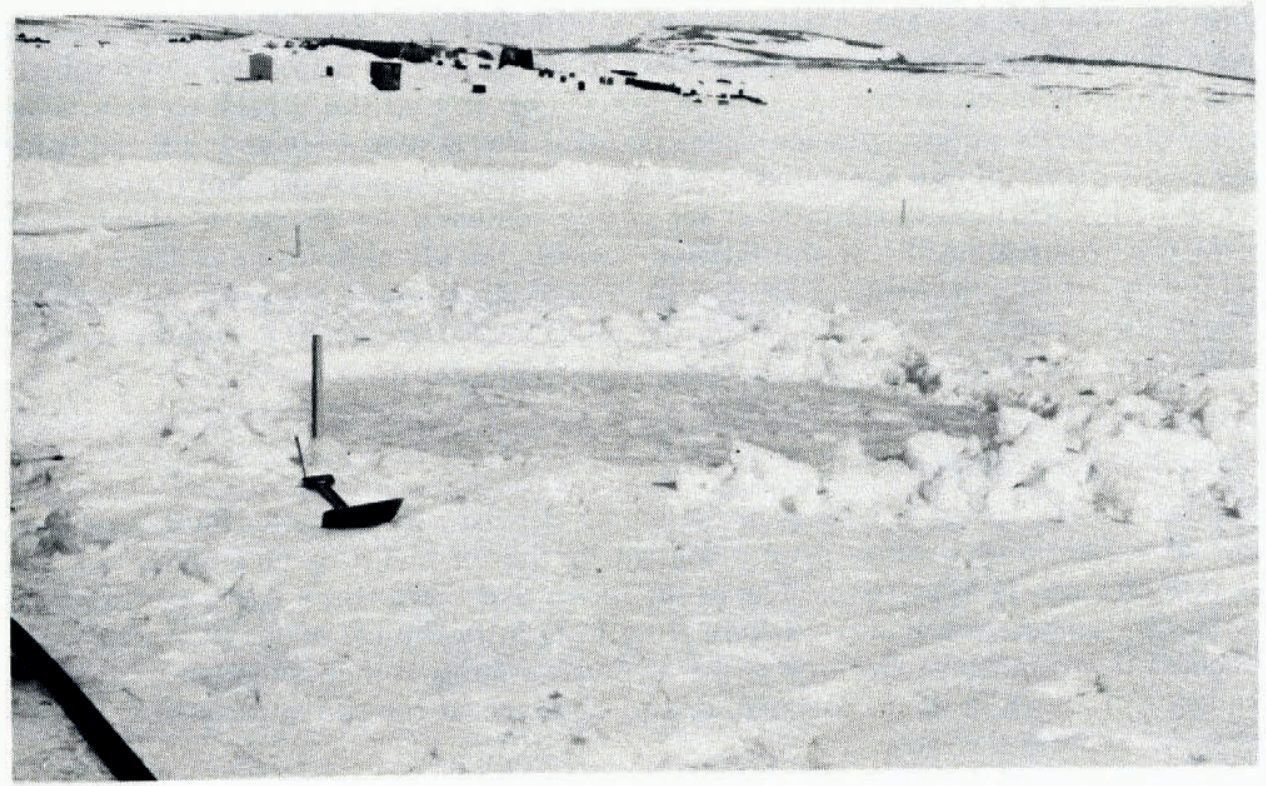

$a$



$b$

Fig. 14. The 15 May 1975 discharge. (a) Site appearance before spill; (b) appearance two hours after spill. 


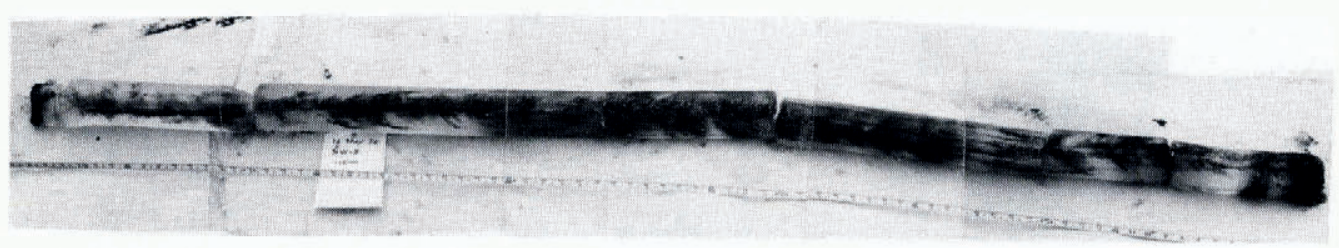

$a$

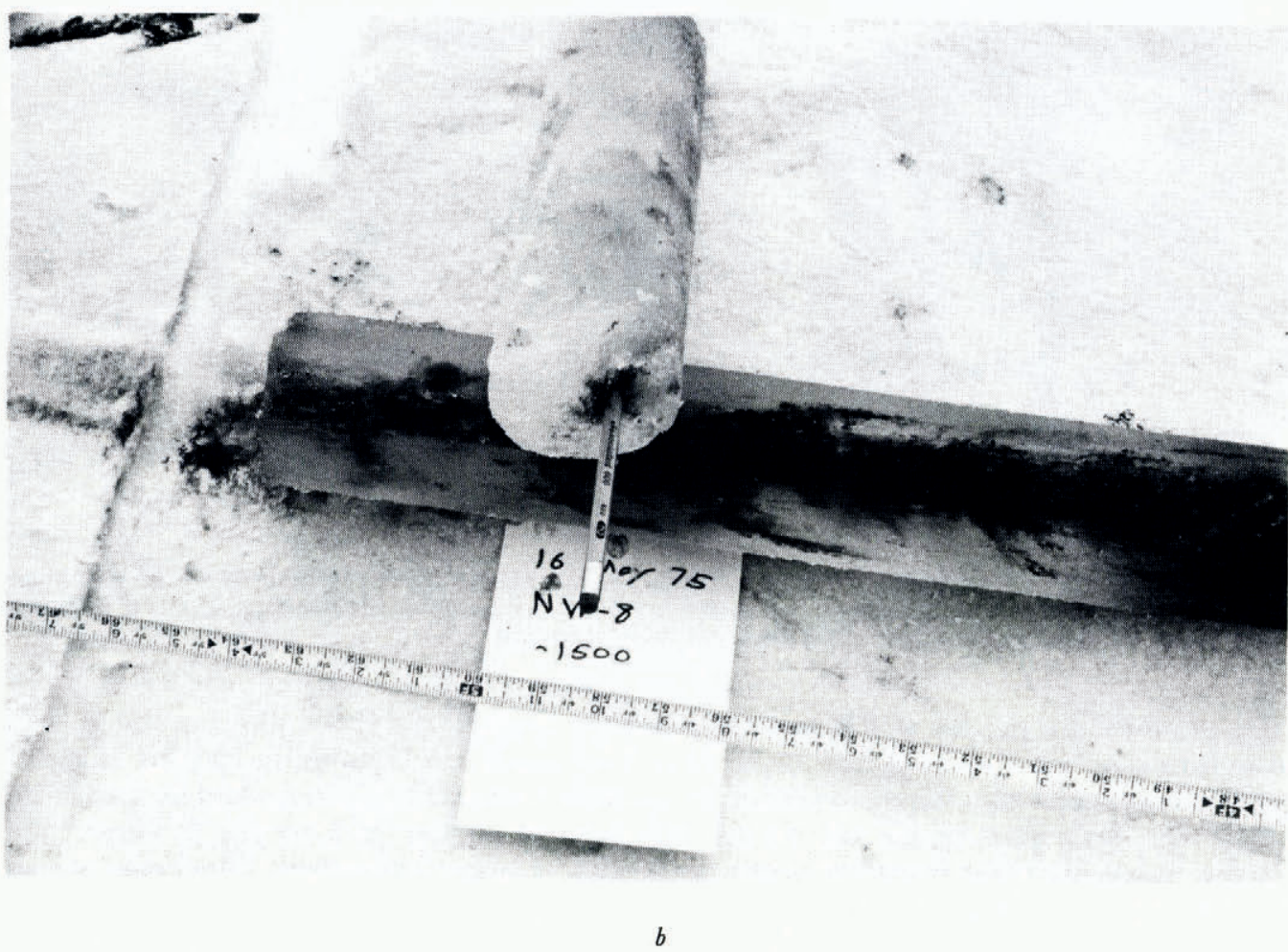

Fig. 15. Core from the I5 May 1975 spill. (a) The total core with bottom at left. (b) Close-up of the ice bottom in (a).

To measure the amount of oil contained in this core, we melted it down and recovered $85 \mathrm{ml}$ of oil and 7.81 of fluid. If we estimate the oil losses caused by oil sticking to the sides of the pails and insides of the plastic bags used to hold the core pieces during the melt-down at I $5 \mathrm{ml}$, then the core contained $100 \mathrm{ml}$ of oil, or a relative oil volume of $1.3 \%$. This estimate neglects the flow of oil out of the large brine channel during our removal of the core. To estimate this loss, we assume that' a $4 \mathrm{~mm}$ diameter channel runs the length of the core to obtain an additional $25 \mathrm{ml}$ of oil, or a relative oil volume of $1.6 \%$. Finally, since the oil rose through $\mathrm{I} .95 \mathrm{~m}$ of ice in $50 \mathrm{~min}$, its rise velocity was $4 \mathrm{~cm} \mathrm{min-1}$ or $0.7 \mathrm{~mm} \mathrm{~s}^{-1}$.

Figure 15 a shows that at the top of the core the oil is absorbed in two horizontal layers. The first layer, which may be snow ice, extends from the ice surface to a depth of $40 \mathrm{~mm}$; the second, which is separated from the first by $30 \mathrm{~mm}$ of ice containing only vertical channels, extends from 70 to $100 \mathrm{~mm}$. This layered structure occurred in most of our cores, including one pulled on the same day $0.5 \mathrm{~m}$ away. The thickness and spacing of these oiled layers varied from core to core. 

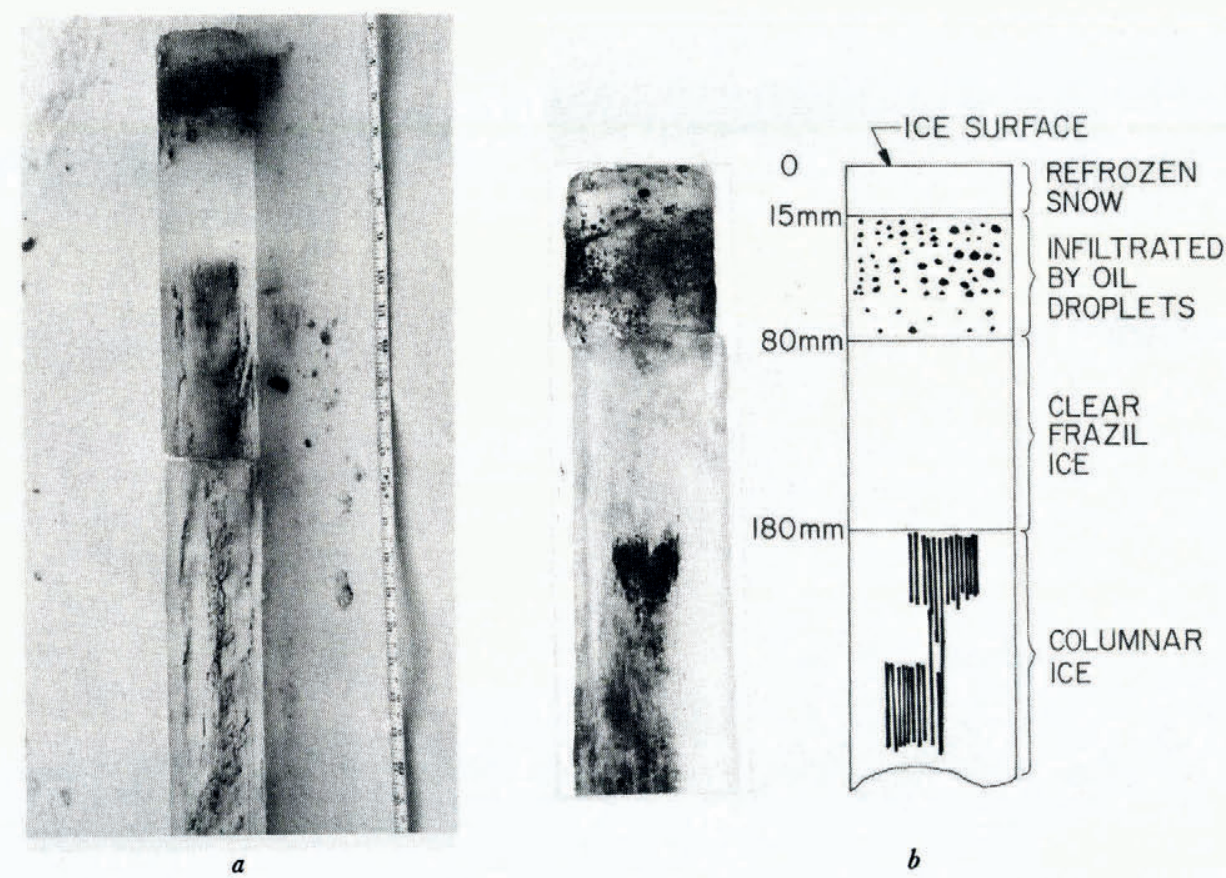

Fig. 16. Oil and the upper part of the ice. (a) The top o.6 $\mathrm{m}$ of a core contaminated with Swan Hills crude oil. (b) Photograph by transmitted light of a $20 \mathrm{~mm}$ thick segment of the upper part of $(a)$ plus an explanatory diagram; see text for additional description. The break in this core at $80 \mathrm{~mm}$ depth occurred during cutting.

To examine the details of this layered structure, Figure $16 \mathrm{a}$ shows the top $0.6 \mathrm{~m}$ of a I.6o $\mathrm{m}$ long core which was pulled on 16 May from the Swan Hills crude spill on 12 April 1975; this core shows that the more viscous Swan Hills crude oil is also entrained in horizontal layers in the upper part of the ice. Figure $16 \mathrm{~b}$ shows a $20 \mathrm{~mm}$ thick section of Figure $16 \mathrm{a}$ taken by transmitted light together with an adjacent schematic diagram. The figure shows the following four separate layers:

a. O-I $5 \mathrm{~mm}$. This layer of nearly clean ice lies above an oily layer. A similar clear zone occurred at the top of many of the cores which we pulled in May, including the surface spill discussed below. The reason this clear ice grows is that once oil rises to the ice surface under the snow, the solar radiation absorbed by the oil causes melting and collapse of the overlaying snow which then refreezes. This process is similar to the formation of the refrozen snow layer shown in Figure 7 a. Further, for the core shown in Figure $15 \mathrm{a}$, where the oil was only on the surface for one day, this clear layer is absent.

b. $15-80 \mathrm{~mm}$. The oil in this zone is trapped within spherical bubbles with the layer of darkest oil within this zone having a thickness of $35 \mathrm{~mm}$. This may be either snow ice which is oil-saturated, or else the result of oil filling the voids left by brine drainage.

c. $80-180 \mathrm{~mm}$. This clear ice is either frazil or slush ice; as evidence, when we held the core segment up to the Sun, we saw within this zone reflections from randomly oriented crystals. We discuss below why this ice is oil free.

d. Below $180 \mathrm{~mm}$. The oil which outlines the individual platelets at the top of this layer shows that this ice is clearly columnar. Also, the abrupt beginning of the columnar growth at $180 \mathrm{~mm}$ resembles the transition from frazil to columnar ice and slush to columnar ice shown respectively in Figures $5 \mathrm{a}$ and $6 \mathrm{a}$. 
The cause of the formation of these oiled and unoiled horizontal layers is probably the interaction of brine drainage with the percolation of melt water down from the surface and the rise of sea-water up from below. For the $2 \mathrm{~m}$ long core shown in Figure 15 a, we measured the water-level or ice freeboard at I I $5^{-1} 30 \mathrm{~mm}$ down from the surface, or at the 5 inch mark on the tape measure in the photograph. On the assumption that the water-line of the $1.6 \mathrm{~m}$ core shown in Figure $\mathrm{I} 6 \mathrm{~b}$ is at the same relative height, its water-line is $100 \mathrm{~mm}$ down from the surface. Since the ice above $180 \mathrm{~mm}$ consists of small, randomly oriented crystals, its drainage may be enhanced by the greater porosity of the small crystals. Our hypothesis is that when the core warmed up during April, the saline near-surface brine drained downward through the newly-opened brine channels. Of course, because the brine within the ice is denser than sea-water, drainage also occurs at depths below the water-line. As the brine drained out, it was replaced in two different ways. Above the water-line, melt water from the snow percolated down into the ice where it refroze, either by heat loss to the colder ice below, or to the atmosphere. Below the water-line, for the core in Figure i 5 a, sea-water flowed up from below to replace the drained brine, and for the core in Figure 16 , sea-water and oil flowed up into the core. Therefore, the percolation of melted snow down from above and the rise of sea-water up from below probably formed the clear ice shown in Figure 16 between 80 and $180 \mathrm{~mm}$. The oiled zone above the clear ice probably remained porous because not enough water percolated down.

This combination of brine channels opening and the formation of porous ice near the ice surface leads to vertical oil entrainment in the lower part of the ice cores and horizontal entrainment in the near-surface layer. We next discuss briefly two more examples of this phenomenon, and then discuss the evolution of the open-water spill on I November I 974 .

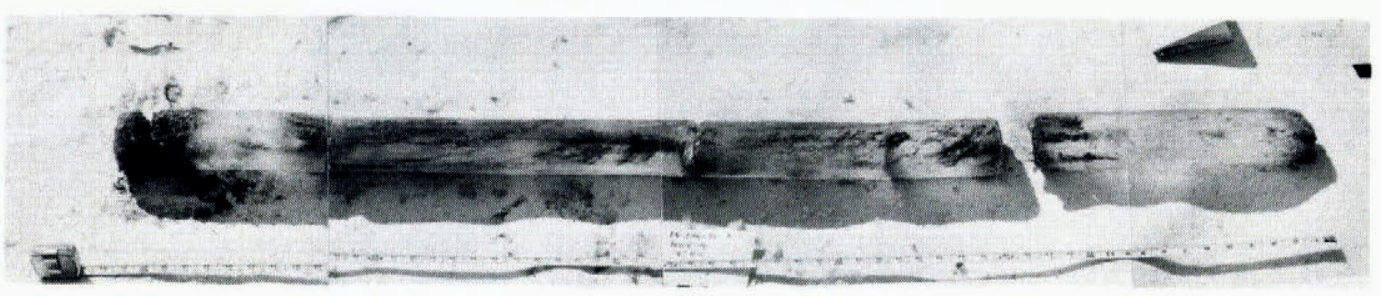

Fig. 17. Core from ${ }_{15}$ February 1975 spill, top is at left.

First, Figure I 7 shows a core pulled on I 5 May I 975 from the Norman Wells crude-oil spill in Balaena Bay on 15 February. This core, which was taken from under $0.25 \mathrm{~m}$ of snow, measured $\mathrm{I} .52 \mathrm{~m}$ in length and had a $40 \mathrm{~mm}$ thick oil lens. As with the previous two cores, the core also had brine channels running up from the lens, an oil-soaked layer at the top of the ice, and a clear layer separating the oiled ice from the region with brine channels.

Second, Figure I8a shows a core taken on 28 May from the NORCOR offshore experiment, which the NORCOR report describes in detail. This experiment, which took place on 8 April 1975 at a site $33 \mathrm{~km}$ north of Cape Parry, involved two Norman Wells crude oil spills of $0.82 \mathrm{~m}^{3}$ each, one under smooth ice and the other near a small pressure ridge. There were no cores taken at this site until 28 May 1975, so that the interaction of oil with the ice was undisturbed by people walking and coring in the area.

For the spill under smooth ice, Figure I8a shows a $1.27 \mathrm{~m}$ core which closely resembles the previously discussed cores. On the core, the location of the oil lens which measured $4 \mathrm{~mm}$ thick is at the break between the clean and oily ice. The core has oiled brine channels running through it with some very dark oil-saturated portions. When we melted down the black part of the core which lies between 8 and 14 inches on the tape measure in the photograph, we 
found $12 \mathrm{ml}$ of oil in $485 \mathrm{ml}$ of fluid or an oil content of $2.5 \%$. The top $150 \mathrm{~mm}$ of the core again shows a zonal oil entrainment; Figure $18 \mathrm{~b}$, a close-up photograph, shows that in the top $30 \mathrm{~mm}$ the oil is segregated into many small droplets with the droplet size increasing with depth. Below these droplets, there is a layer of clear ice $45 \mathrm{~mm}$ thick containing air bubbles and air chanels, and below this is a layer $75 \mathrm{~mm}$ thick containing a uniform distribution of oil droplets with I-2 mm diameters. Below this layer, brine channels fill the ice. The cause of this remarkable oil distribution is presumably again the interaction of melt water, brine drainage, and oil.

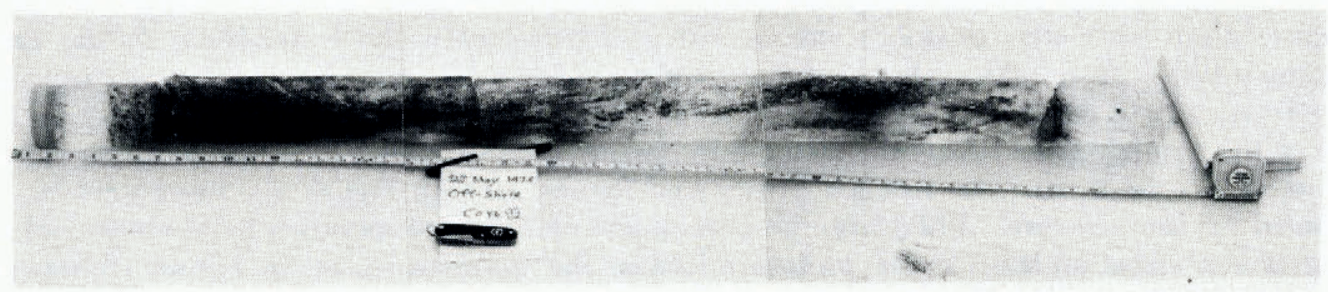

$a$

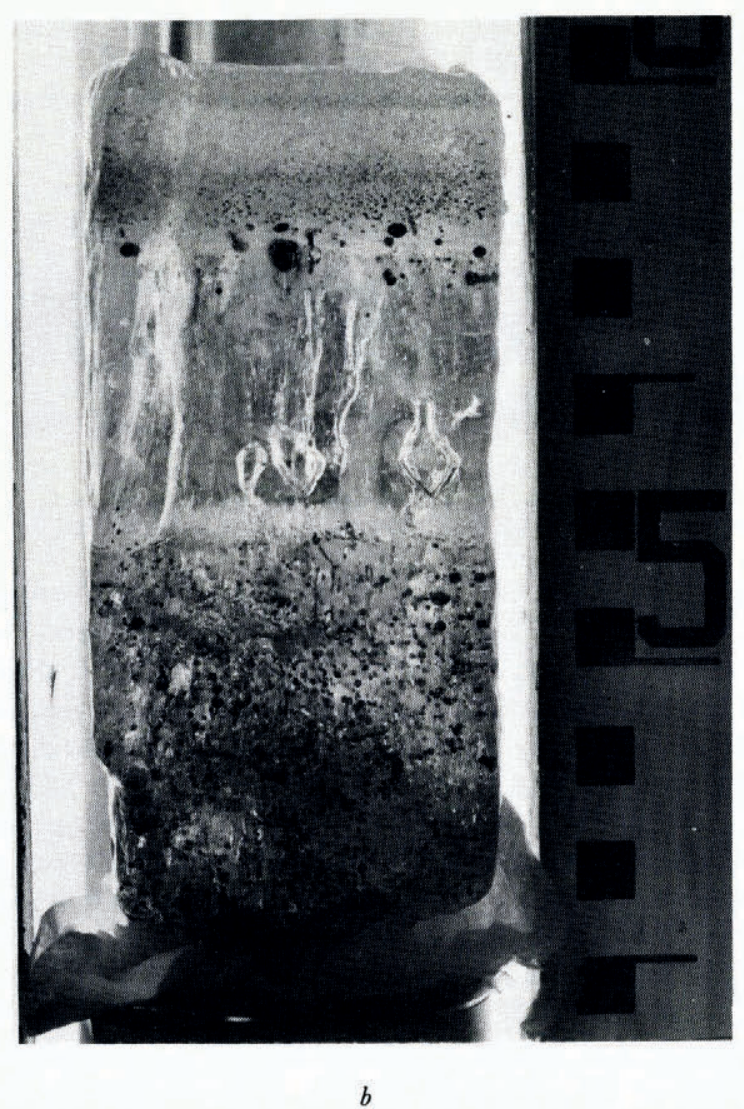

Fig. I8. Core taken at the offshore experiment on 28 May 1975. (a) The total core with the top at left. (b) Photograph with transmitted light of the upper part of the core in $(a)$. Scale at right is in centimeters. 
Finally, Figure 19 shows the upper $0.3 \mathrm{~m}$ of a core pulled on $\mathrm{I}_{5}$ May 1975 under $0.25 \mathrm{~m}$ of snow from the open-water spill on I November I974. This spill took place in a $36 \mathrm{~m}^{2}$ open area which was cut into the ice. Approximately $0.4 \mathrm{~m}^{2}$ of Norman Wells crude oil was poured on this open area to a depth of about I I mm. On I 5 November we observed that the oil had mixed with snow to form a dry granulated mixture at $-28^{\circ} \mathrm{C}$. By spring the oil was entirely snow-covered. Figure 19 shows that about $50 \mathrm{~mm}$ of clear ice grew above the oil, and that no oil flowed down into the core. When we melted down the oily part of this core, we found ro $\mathrm{ml}$ of oil in $140 \mathrm{ml}$ of fluid or a $7 \%$ oil volume. The cause of the growth of unoiled ice above the oil layer is again the interaction of solar radiation with the oil layer.

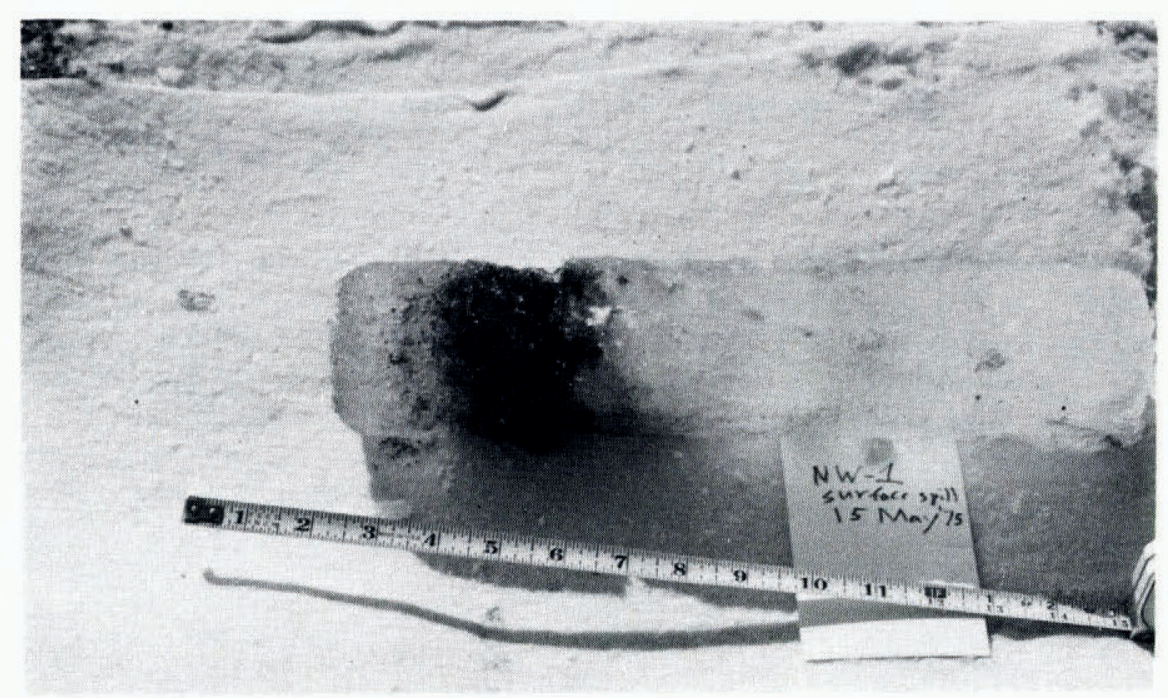

Fig. 19. Upper $0.3 \mathrm{~m}$ of core from surface spill taken on ${ }_{15}$ May 1975, top is at left.

\section{Two special Gases}

There were two spills during the field tests which do not fit into the previous discussion. The first of these was the entrainment of oil spilled adjacent to a small pressure ridge at the offshore site; the second was an oil spill under columnar ice which grew with parallel $c$-axes. We next discuss these two cases in detail.

\section{I. The spill adjacent to a pressure ridge}

On 8 April $1975,0.82 \mathrm{~m}^{3}$ of Norman Wells crude oil was spilled at the offshore site under the ice adjacent to a small weathered pressure ridge. Observations by divers showed that much of this oil was trapped to a depth of o. $\mathrm{I} \mathrm{m}$ in a cavity adjacent to the ridge keel. On 3o May 1975 we visited the site and found that oil on the surface clearly marked the location of the under-ice spill. We took three cores on a line perpendicular to the ridge across the spill; Figure 20 is a sketch of the resultant core configuration; and Figure 21 shows the core photographs. The cores confirmed the divers' observations that most of the oil was trapped in a deep cavity with a thin sheet spread out on the sides. The figures also show for the core in Figure 2 a, the likely penetration of oil down from the surface into the snow ice. 
496

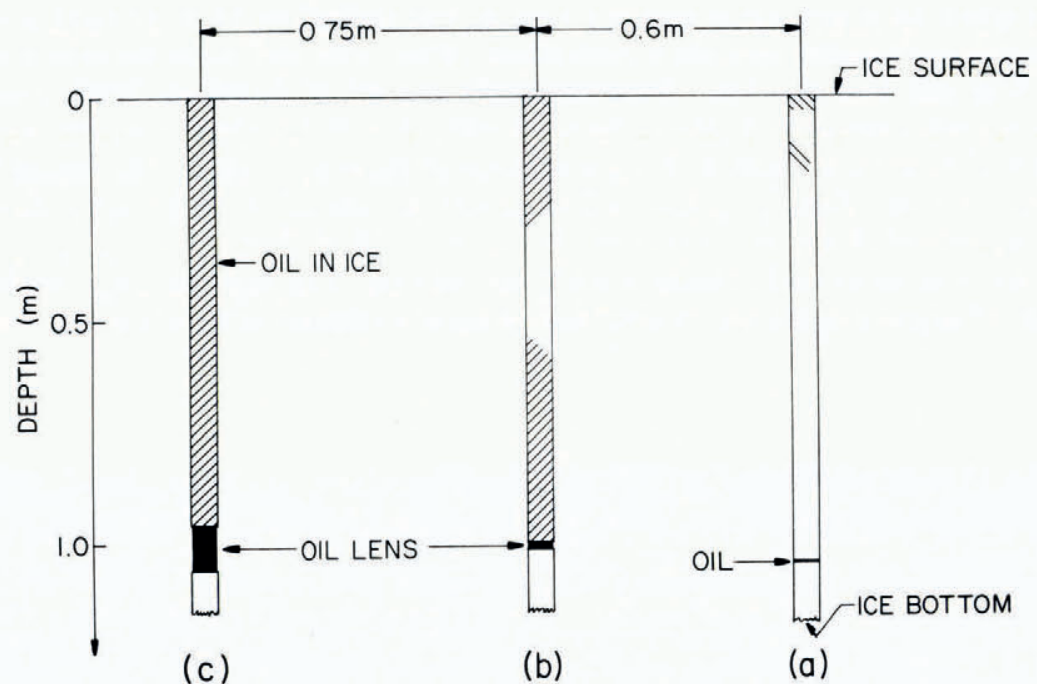

Fig. 20. Sketch of the configuration of the three cores pulled near the pressure ridge. The letters at the bottom of each core refer to Figure 21 .

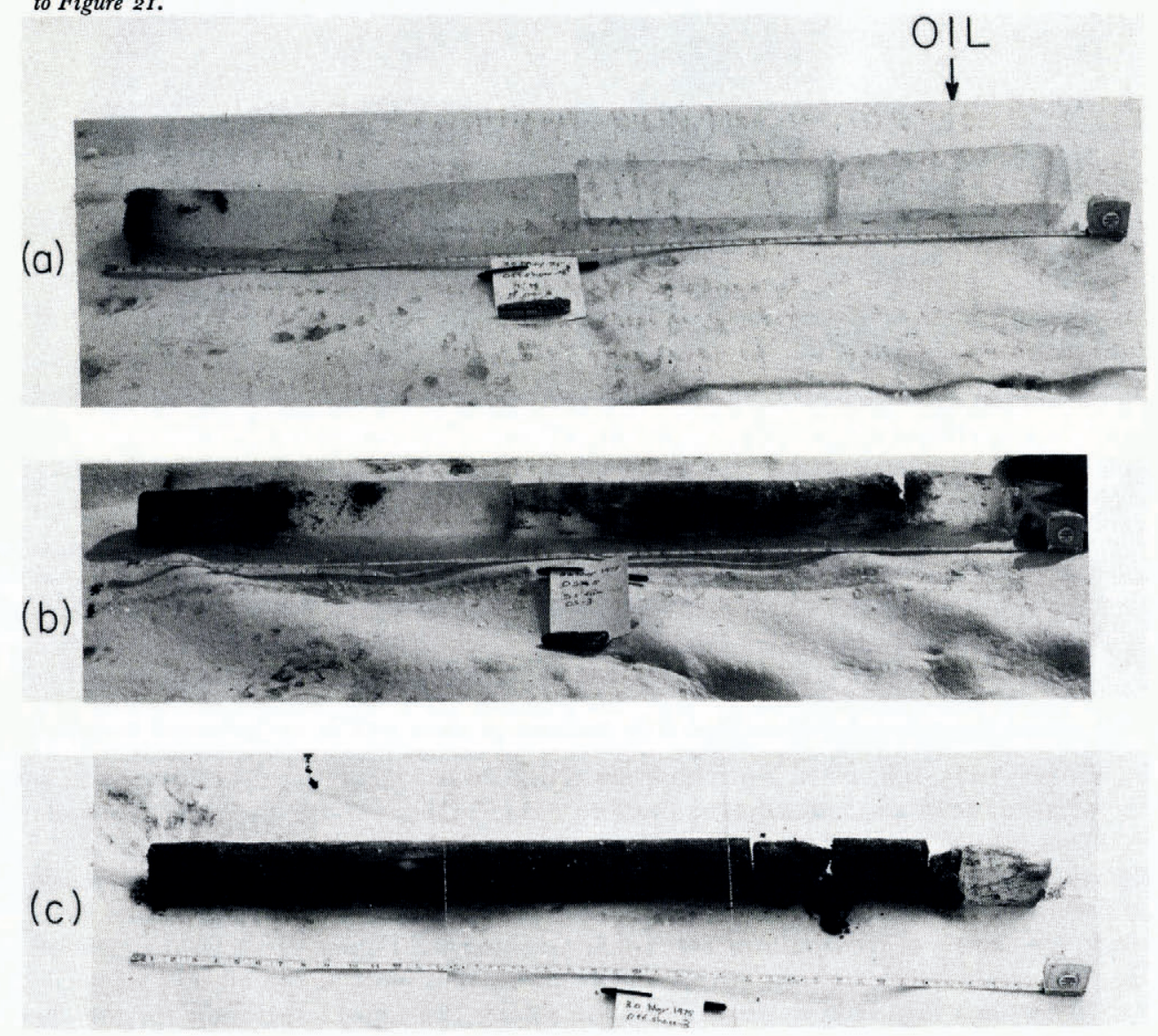

Fig. 21. Photographs of the three cores shown in Figure 20. 
The blackest core observed in the field experiment is the core in Figure 2 Ic. When we melted down that core segment which is just above the first break down from the top in the figure, we found $30 \mathrm{ml}$ of oil in $910 \mathrm{ml}$ of total liquid or an oil concentration of $3.3 \%$, so that again, a relatively small amount of oil produces very dark cores. This particular core was over an oil lens roo mm thick and, after taking the core, pure oil from the lens flowed up to the surface. At the adjacent holes oil did not rise to the surface; rather the thin oil lenses were frozen into the cores.

Figure $2 \mathrm{I}$ also shows that the new ice growth beneath the oil lenses appears clean and free of oil. For the black core in Figure 2 I c, Figure 22, a close-up photograph of the ice surface which grew beneath the oil, shows that a fine wave-like fluting covers the surface. Because this ice formed beneath $h=100 \mathrm{~mm}$ of oil, the Rayleigh number within the layer was probably large when the new ice formed. The fluting on this new ice surface, then, was probably caused by turbulent convection associated with the large Rayleigh number within the oil layer.

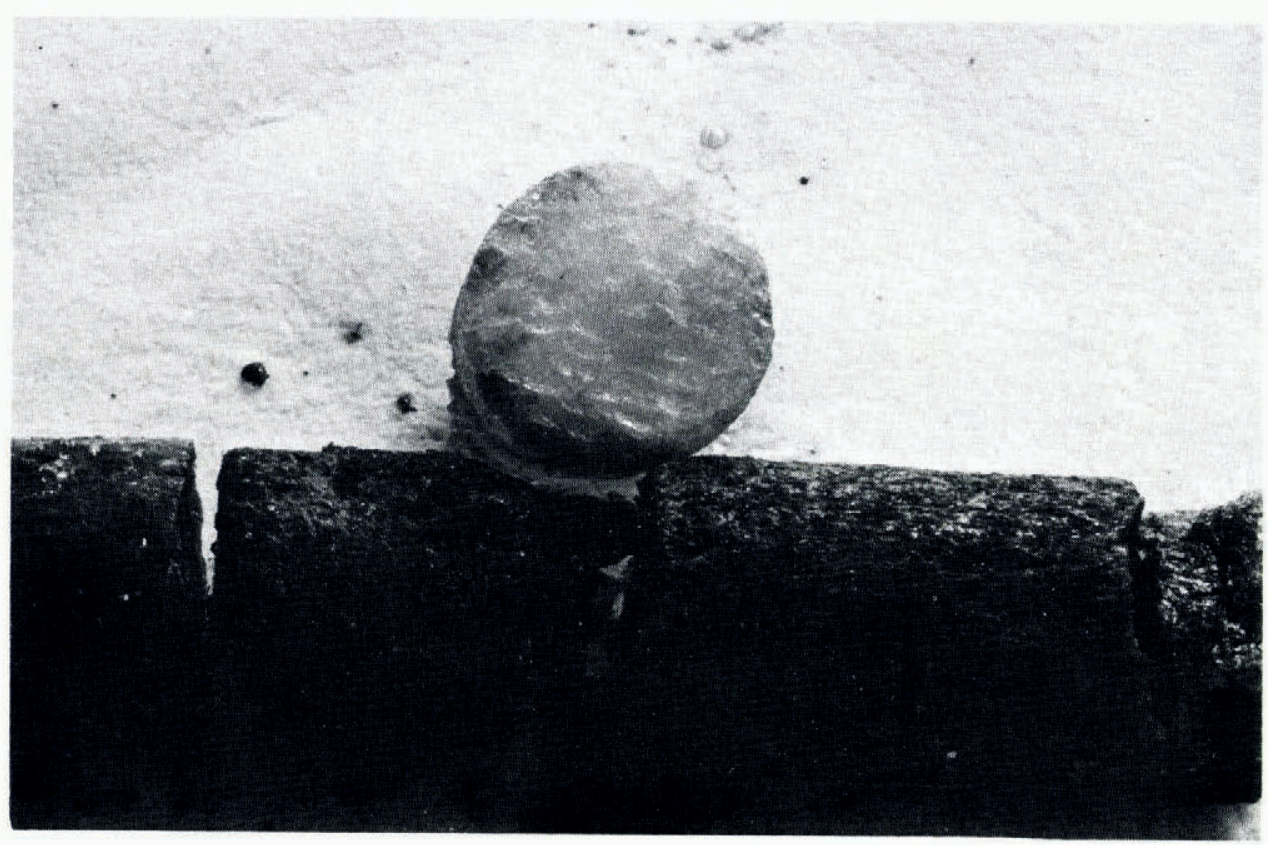

Fig. 22. Close-up photograph of the ice beneath the oil lens for core " $c$ " in Figure $2 I$.

\subsection{Oil absorption in parallel-crystal sea ice}

Weeks and Gow (1978) review the literature and describe their field study of cases when columnar sea ice has a preferred crystal orientation. They show that for shore-fast ice along the Alaskan coast, the $c$-axes of the columnar platelets are predominately aligned parallel to the coast, which they attribute to ice response to long-shore currents. In one part of the Balaena Bay site, we found an area where the platelets were aligned in the same direction and saturated with oil. The importance of this observation is that a section of a core from this ice had an oil volume of $5.5 \%$, which was the largest oil volume within the ice observed at the site. 
Figure 23 shows two schematic drawings at right angles to one another of the core which was pulled on 2 I May 1975 under $0.43 \mathrm{~m}$ of snow from the Norman Wells oil spill of 15 April 1975. The approximately $60 \mathrm{~mm}$ of new growth beneath the oil is not shown. The photographs in Figure 24 show a view of the core perpendicular to the platelets; between the depths of 0.6 and $1.45 \mathrm{~m}$, plane parallel diagonal feeder channels fill the core. These feeders have a vertical spacing of 5 to $10 \mathrm{~mm}$ and lie at an angle to the horizontal of approximately $40^{\circ}$. Also, the top $150 \mathrm{~mm}$ of the core again show the alternating layers of clear and oil-soaked ice, with the top $50 \mathrm{~mm}$ being very dark.

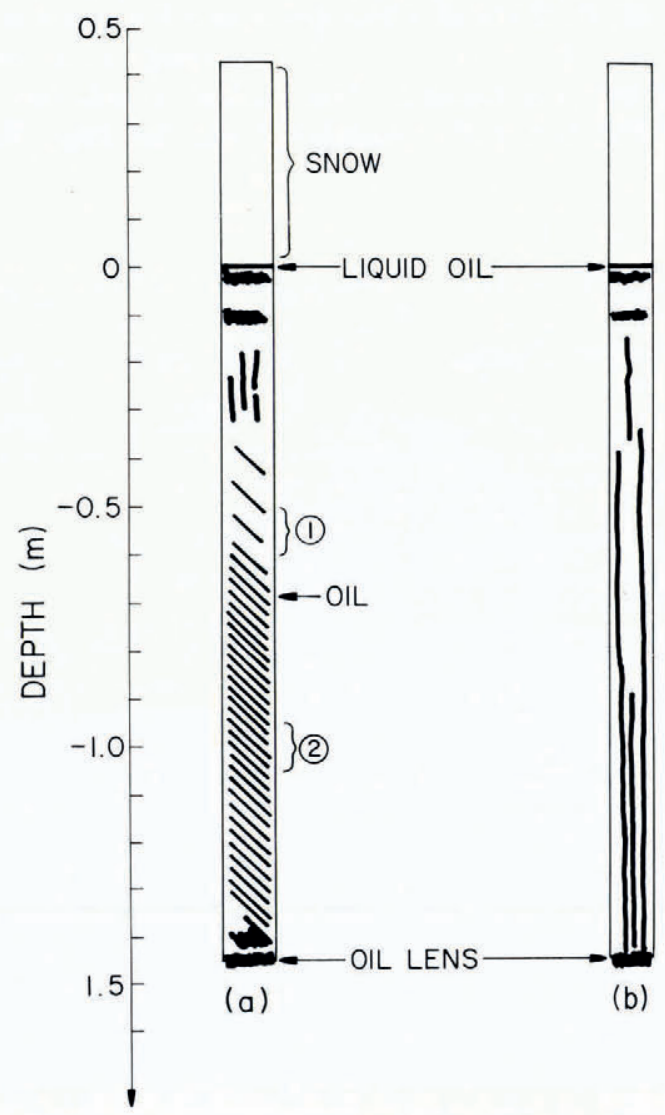

Fig. 23. Schematic diagram of the feeder-channel distribution for the core pulled on 21 May 1975. View in (a) is at $90^{\circ}$ to the view in $(b)$.

From the core sections marked $\mathrm{I}$ and 2 in Figure 23, we cut thin horizontal and vertical sections. Figure 25 shows the two views from section $\mathrm{I}$; the vertical in $25^{\mathrm{a}}$ and the horizontal in $25 \mathrm{~b}$. In $25 \mathrm{a}$, the channels are nearly vertical; while in $25 \mathrm{~b}$, the crystal platelets are oriented in about three directions, with a predominant slope from upper left to lower right. Figure 26 shows a similar horizontal and vertical section from the lower part of the core in section 2 . Figure $26 \mathrm{a}$ shows that the crystal platelets almost all lie in the same plane; and $26 \mathrm{~b}$, which is taken parallel to the crystal planes, show that the feeder channels have the same slope. The photographs also show that within the ice, the oil is entrained both in brine channels and between the crystal platelets. When we melted down an ice sample near section 2, we found 




Fig. 24. Photograph of core sketched in Figure 23a. Top of core is at upper left; bottom is at lower right.

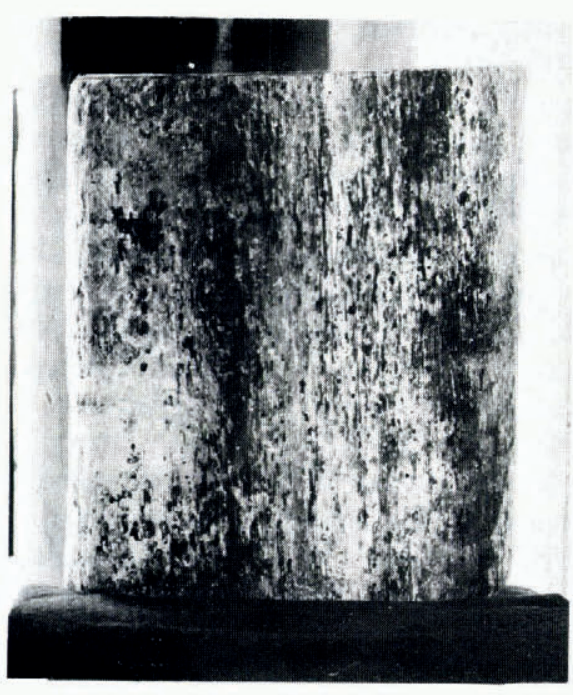

$a$

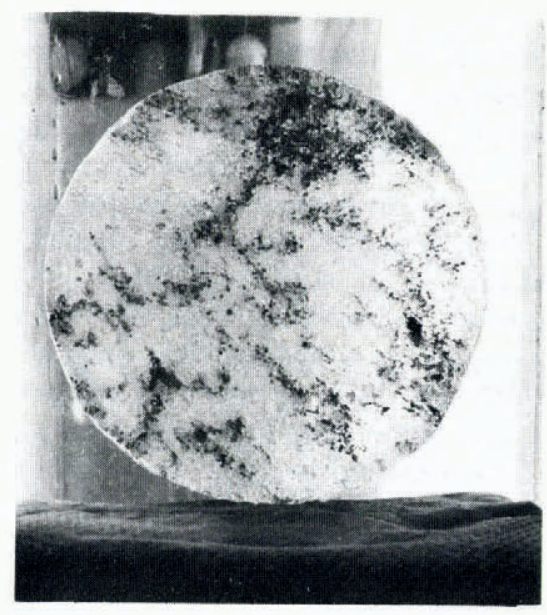

$b$

Fig. 25. Detail of core from section marked " $I$ " in Figure 23. (a) Vertical section. (b) Horizontal section. 
$30 \mathrm{ml}$ of oil in $550 \mathrm{ml}$ of fluid or an oil volume of $5.5 \%$. This was the largest oil volume observed within the ice during the field experiment, and suggests that large feeder channel systems within plane parallel crystals may absorb more oil than ice with non-aligned crystals.

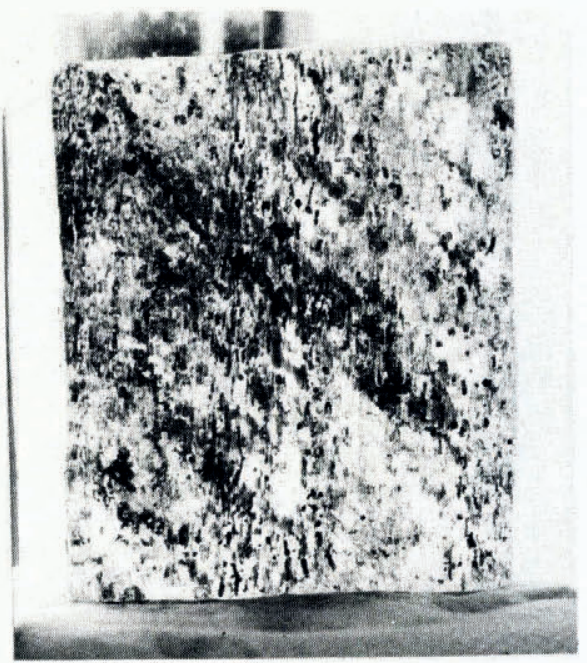

$a$

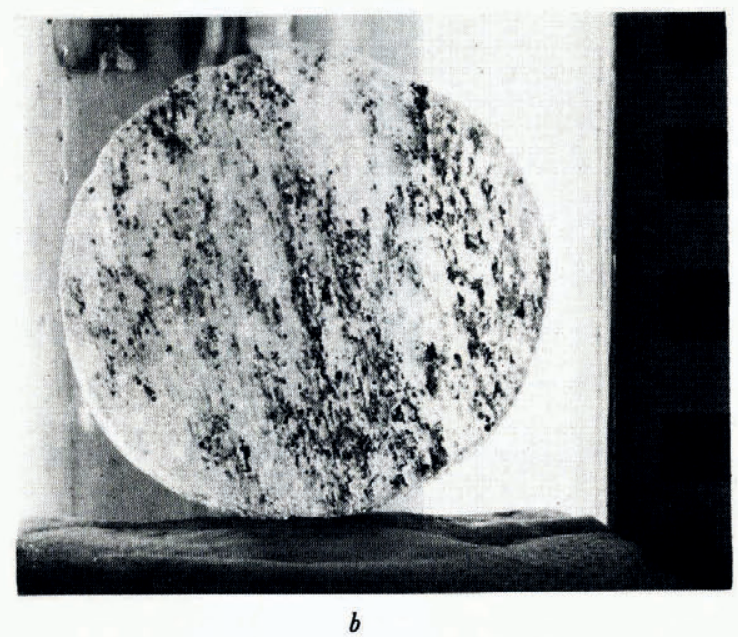

Fig. 26. Detail of core from section marked " 2 " in Figure 23. (a) Vertical section. (b) Horizontal section.

\section{Oil on the surface}

Once the oil came to the ice surface, it spread laterally both within and on the ice under the snow. The oil affected the snow appearance in two ways. First, the snow color changed from white to light yellow; second, because of the radiation effects described in the previous sections, the snow subsided over the oil. Even for snow depths of up to $0.3 \mathrm{~m}$, this color and depth change of the snow generally marked the oil location.

By late May, the combination of warm weather and solar radiation led to the formation of melt ponds on the ice above the oil lenses. Once melt ponds form, the oil floats on the water surface, and the thermal convection induced by the heating of the surface oil leads to a rapid growth in both area and depth of the ponds. The NORCOR report (Anonymous, 1975, p. 56-58, 129) describes the evolution of the oiled melt ponds. To summarize, after the melt ponds form, the thickness of the oil slick on the pond surface increases from the continuing upward migration of oil through the ice. For slicks with thicknesses on the order of $10 \mathrm{~mm}$, the absorbed radiation increased the slick temperature as much as $5 \mathrm{deg}$ above the ambient (Anonymous, 1975, fig. 6-15), so that the melt ponds grew rapidly in both depth and extent. The winds also had an effect on melt-pond growth. The NORCOR report (Anonymous, 1975, p. 57) states that "in strong winds, some of the oil was carried up onto the surrounding snow. This resulted in rapid melting in the splash zone and a further expansion of the melt pool beyond the boundary originally defined by the oil lens in the ice sheet. Horizontal seepage at the snow-ice interface also contributed to the expansion of the pools into areas of clean ice".

The ponds continued to grow in both depth and extent until they melted through the ice. To continue from the NORCOR report (Anonymous, I975, p. 57), "On June 4, an old core hole in the ... test area opened, creating a drain, and water from the surrounding melt pools 
started to flow toward the hole. A considerable vortex was established as both water and oil were flushed down the hole". The report also implies (p. I 29) that as the water-oil mixture drained from the pool, some of the oil coated the sides of the melt ponds. Finally, when the field crew examined the underside of the ice with a video system, they discovered that the oil swept down the hole was deposited on the ice bottom within $2 \mathrm{~m}$ of the core hole.

At the test site, this drainage was blamed on the presence of old core holes within the ice. Other observers, however, have seen such drainage occur in unoiled melt ponds. From the Fram drift, Nansen ( 1897 , Vol. I, p. 454-55) describes a large melt pond on I 2 July I894, which was large enough for the sailing and rowing of small boats on its surface as a "favorite evening amusement". To continue from Nansen, "a few days afterwards I was dismayed to find the pool dried up; a hole had been worn through the ice at the bottom, and all the fresh water had drained out into the sea. So that amusement came to an end". The above references suggest that the oil, once on the ice surface, will be reintroduced to the ocean in a weathered or emulsified form, either by melting through to the ice bottom or by flowing off the sides of the ice. If left alone, the fate of the oil then is to be reintroduced into the sea-water in the period June-August.

\section{Acknowledgements}

The data for unoiled ice were taken by the author with the help of Messrs Peter Kauffman, Edward Josberger, Terren Niedrauer, and Steven Soltar. I am especially grateful to Peter Kauffman for the design and construction of much of the field apparatus. The photographs of unoiled core in this report are by Peter Kauffman; the photographs of oiled core are by the author. The data on the behavior of oil in ice come from my work as a consultant with the NORCOR corporation at Balaena Bay. I thank Mr Richard F. Brown for his invitation to participate in that project, for permission to use Figures I I and I 3 , as well as several of my photographs which also appear in the NORCOR report, and for many useful conversations. I also thank Messrs David Dickins, John Overall, David Lapp, and George Green for useful conversations and support at Balaena Bay; Mrs Sandra Brown and Messrs Tom Kitchen and Oscar Mullerbeck provided additional logistic and field support. I also thank Mr Robert A. Lake for many useful talks, and for permission to use his previously unpublished Figure 8 in the present paper, and Dr William Campbell for his help and support during the early stages of the preparation of this paper. Finally, Mrs Miriam Lorette, Dr Gunter Weller, and Mr Ted Flesher provided logistic support for the field work with unoiled sea ice. The field work on unoiled ice and part of the writing was supported by the Bureau of Land Management through an interagency agreement with the National Oceanic and Atmospheric Administration, under which a multi-year program responding to the needs of petroleum development of the Alaskan continental shelf is managed by the Outer Continental Shelf Environmental Assessment Program (OCSEAP) Office. The author also gratefully acknowledges the support of the NORCOR corporation for the field work on unoiled ice. Finally, for support of some of the writing and photographic processing, the author also gratefully acknowledges the support of the Office of Naval Research under Task No. NR307-252 and Contract No. Nooo I4-76-C0234.

MS. received 22 December 1978 and in revised form g February 1979 


\section{REFERENCES}

Anonymous. 1975. The interaction of crude oil with Arctic sea ice. Victoria, B.C., Environment Canada. Beaufort Sea Project. (Beaufort Sea Technical Report No. 27.)

Lake, R. A., and Lewis, E. L. 1970. Salt rejection by sea ice during growth. Fournal of Geophysical Research, Vol. 75, No. 3 , p. $583-97$.

Lewis, E. L. 1967. Heat flow through winter ice. (In Oura, H., ed. Physics of snow and ice: international conference on low temperature science.... rg66.... Proceedings, Vol. I, Pt. I. [Sapporo], Institute of Low Temperature Science, Hokkaido University, p. 6 I I-3r.)

Lewis, E. L. 1976. Oil in sea ice. Victoria, B.C., Environment Canada. Institute of Ocean Sciences. (Pacific Marine Science Report 76-12.)

Martin, S., and others. I979. A laboratory study of the dispersion of crude oil within sea ice grown in a wave field, [by] S. Martin, P. Kauffman, and P. E. Welander. (In Science in Alaska, 1976. Proceedings [of the] twentyseventh Alaska Science Conference, Fairbanks, Alaska, August 4 to August 7, 1976, Vol. 2, p. 261-87.)

Nansen, F. 1897. Farthest north. New York, Harper and Brothers. 2 vols.

Nelson, R. K. 1969. Hunters of the northern ice. Chicago, University of Chicago Press.

Ramseier, R. O., and others. 1975. Mesoscale description for the principal Bering Sea ice experiment, [by] R. O. Ramseier, P. Gloersen, W. J. Campbell, and T. C. Chang. (In Kondrat'yev, K. Ya., and others, ed. Sovetskoamerikanskiy eksperiment "Bering". Trudy zaklyuchitel'nogo simpoziuma po itogam sovmestnoy sovetsko-amerikanskoy ekspeditsii. Leningrad, I2-I7 maya 1974 g. [U.S.S.R./U.S.A. Bering Sea experiment. Proceedings of the final symposium of the joint Soviet-American expedition. Leningrad, I2-I7 May 1974]. [Edited by] K. Ya. Kondrat'yev, Yu. I. Rabinovich, W. Nordberg. Leningrad, Gidrometeoizdat, p. 234-7o.)

Weeks, W. F. 1976. Sea ice conditions in the Arctic. AIDJEX Bulletin, No. 34, p. 173-206.

Weeks, W. F., and Gow, A. J. 1978. Preferred crystal orientation in the fast ice along the margins of the Arctic Ocean. Fournal of Geophysical Research, Vol. 83, No. Cio, p. 5105-22.

Weeks, W. F., and Lee, O. S. 1962 . The salinity distribution in young sea ice. Arctic, Vol. 15, No. 2, p. 92-108.

Wolfe, L. S. Unpublished. Some effects of oil spills under sea ice. [S.M. thesis, Dept. of Mechanical Engineering, Massachusetts Institute of Technology, 1972.]

Wolfe, L. S., and Hoult, D. P. 1974. Effects of oil under sea ice. Fournal of Glaciology, Vol. I3, No. 69, p. 473-88. 